Article

\title{
Communications on Technological Innovations: Potable Water Reuse
}

\author{
Cecilia Tortajada ${ }^{1, *(D)}$ and Sunil Nambiar ${ }^{2}$ \\ 1 Institute of Water Policy, Lee Kuan Yew School of Public Policy, National University of Singapore, \\ Singapore, 129792 \\ 2 Department of Politics and International Studies, University of Cambridge, Cambridge CB3 9DT, UK; \\ sn534@cam.ac.uk \\ * Correspondence: cecilia.tortajada@nus.edu.sg; Tel.: +65-6601-3933
}

Received: 26 December 2018; Accepted: 29 January 2019; Published: 31 January 2019

check for updates

\begin{abstract}
Water scarcity has prompted an increasing number of cities to look for non-conventional sources of clean water. One of these sources is reused water, or highly treated reclaimed or recycled wastewater, a worthy addition to the portfolio of water-resource alternatives that increasing cities are considering in view of demographic and environmental changes. In this paper, we analyse communications from the media, policymakers and utility managers on the technology used to produce reused water for potable purposes. The focus of our analysis is technology as a means for producing safe and reliable water supply in the long-term. Three places were selected because of their differing experiences with social acceptance: Singapore, Orange County (California, United States), and Queensland (Australia). We found distinct differences in the communications used in the three places, which we believe have strongly influenced public opinion on the provision of clean water through potable water reuse. In communicating technological innovations to the public, it is essential to also discuss the broader framework affecting reliable water supplies. In this light, planning, legal and regulatory frameworks, institutional coordination, financial sustainability, and operational aspects should also be communicated.
\end{abstract}

Keywords: potable water reuse; technological innovations; media; Singapore; Orange County; Queensland

\section{Introduction}

Demand for water is steadily increasing all over the world. Limited availability due to physical scarcity, pollution, poor management and/or competing uses by different sectors is constraining the amount of water available for all uses. Population growth, urbanisation and industrialisation, as well as climate variability and change, have contributed to making water availability a serious concern.

Water scarcity is becoming a catalyst for policy change. A growing number of cities are developing, or considering strategies that involve diversifying sources of water beyond traditional sources. These alternatives include non-conventional sources of water for potable and non-potable uses, such as treated wastewater, agricultural drainage water, reused water (highly treated reclaimed or recycled wastewater) and desalination. They also consider more stringent water conservation efforts to promote more efficient use of water in the domestic, commercial, industrial and agricultural sectors.

Normally, wastewater effluent produced in any city is treated to a certain level and then discharged into a body of water, where it is blended with the natural flow. The blended water is then treated and reused by cities downstream. This means that, under normal circumstances, wastewater effluents are part of potable water supplies. In an assessment of de facto wastewater reuse in the United States [1], it was found that municipal flows upstream of drinking water treatment plants increased $68 \%$ between 
1980 and 2008, with potential risks for human and environmental health. The California Department of Health had recommended that wastewater contributions to a drinking water source be kept under 10 percent to avoid chemical hazards. However, six of the 25 cities exceeded this limit under average long-term streamflow conditions. This is likely to be the situation in every city all over the world.

Wastewater can be treated to a high quality and used for potable and non-potable uses. This can effectively increase the quantity of water available for the domestic, industrial and agricultural sectors. In the domestic sector, a growing number of cities are considering treating municipal wastewater to a high quality for potable water reuse. This water can be supplied to customers either directly or indirectly. Although definitions vary, in general, in indirect potable reuse (IPR) systems, treated water is introduced into or stored in environmental buffers (either surface or groundwater), re-abstracted, treated again and distributed to the population.

In direct potable reuse (DPR) systems, there is no environmental buffer or external dilution. After extensive treatment and monitoring to assure that strict quality requirements are met at all times, the purified water is introduced to a municipal water supply system for distribution to consumers [2]. In all cases, potable reused water has to meet specific drinking water standards before distribution [2-4].

Potable reused water's potential to augment water resources has been widely acknowledged. Meanwhile, human and environmental health are strong concerns for policymakers, regulators, the public and the media. Providers of reused water for potable purposes are under close scrutiny for compliance with state and federal water quality laws and regulations. To build trust, utility providers are expected to demonstrate institutional competence, adherence to robust safety and public health protocols, the use of independent experts for evaluation purposes, and stakeholder engagement in project development, while always considering social and environmental impacts [5]. They are also expected to present long-term urban water management plans to which potable water reuse will contribute. Public messaging should make clear that institutional coordination and regulatory, management and technological advances in potable reuse can and will reduce the concentration of chemical and microbial contaminants to levels comparable to or lower than those in many high-quality drinking water supplies [6].

Potable reuse is increasing in the US [7], perhaps to the extent that it can be considered a trend. It is also growing elsewhere, such as in Windhoek, Namibia, Australia, Belgium, France, United Kingdom, Singapore and South Africa. It is often mentioned in the context of meeting the water needs of increasing populations under changing climate conditions. The US is the country with the largest number of potable reuse projects; total water reuse has grown at 15 percent/year. It increased from 4000 million litres/day (MLD) (1057 million gallons/day, MGD) in 1995 to 6400 MLD (1690 MGD in 2004) [8]. According to the US National Research Council [6], the source of potable reuse is the approximately 121 billion litres/day ( 32 billion gallons/day) of municipal wastewater that is produced at the national level. Of this amount, only about 7-8 percent is reclaimed [7].

An increasing number of studies, some of them from the 1970s [9], have analysed not only the regulatory, environmental and health aspects of potable water reuse but also aspects such as communication, perceptions and community outreach, for long-term project implementation. There are projects that have stalled due to institutional, technical, financial or managerial difficulties, or for political reasons. However, a common cause has beenthat the benefits of the projects in terms of availability of safe water, versus the risks and the measures to safeguard the population against those risks have not been communicated clearly, resulting in public opposition [10]. The best-known examples are San Diego in US in 1999 [11] and Toowoomba in Australia in 2006 [12]. As the need for potable reuse increases, so does the importance of public communication, education and engagement [9].

Public communication, through the media, plays a central role in the development of sound policies, constructing and reflecting social norms [13]. The overall policy of potable water reuse is to ensure provision of safe and reliable water supplies for drinking purposes, for growing populations, under changing environmental conditions. Given the contributions potable water reuse can make 
towards this end, relations with the public need to go beyond information and communication to active engagement, where people are made part of the initiatives rather than merely being affected by them.

Social response is more positive when utilities are trusted; when there is a relationship between water utility providers with the public; when community, medical and business groups are involved; when messages are clear, sustained and consistent; when the focus is on innovations (policy or technology-wise); and when it is guaranteed that potable reused water will be safe and reliable [10,14-16]. These elements are essential to ensure that projects are assessed more objectively, based on their impacts and benefits, rather than by the source of the water. This is critical so that water augmentation projects, which may be necessary for water security, do not stall [17].

In this paper, we analyse public communications in relation to potable reused water. The focus of our analysis is communications on technological innovation as a proxy for safe and reliable sources of water for potable reuse. We have selected two places where potable water reuse has been implemented sustainably (Singapore and Orange County, California, USA) and one where projects are stalled because of public opposition (Queensland, Australia).

Cities for this analysis were selected because of their differing experiences with fostering social acceptance of potable reuse. With human and environmental health being the main concerns of the public, the topics we decided to study are how potable reuse has been framed in relation to health and safety, and technology.

\subsection{Singapore}

Singapore is a Southeast Asian city-state that, in 2018, marked 53 years of independence. Its population of 5.6 million in an area of $719 \mathrm{~km}^{2}$ [18] makes it one of the most densely populated countries in the world. Its Gross Domestic Product (GDP) of $\$ \$ 402,159$ billion [19] makes it one of the world's wealthiest nations. Singapore's per capita GDP is the seventh-highest in the world on a purchasing power parity basis [20]. The Public Utilities Board (PUB) is the national water agency that manages Singapore's water supply, water catchment and used water (wastewater) in an integrated way. Water quality is regulated by the Environmental Public Health (Quality of Piped Drinking Water) Regulations of 2008. Drinking water standards in these regulations are based on the WHO guidelines.

With a 100 percent sewer connection, all wastewater is collected and treated [21]. Introduced in 2002, reused water for potable and non-potable uses-branded NEWater-is one of the city-state's four water sources, the other three being local catchments, water imported from Johor, Malaysia, and desalinated water [22]. The NEWater strategy includes technological development, regulations, and safety and public health protocols, as well as a robust engagement programme meant to inform the media and the public on the benefits and safety of the water [23]. NEWater accounts for up to 40 percent of water demand. It is supplied from five NEWater factories with total capacities of 122 $\operatorname{MGD}\left(554,600 \mathrm{~m}^{3} /\right.$ day). Production is projected to reach some $192 \operatorname{MGD}\left(873,000 \mathrm{~m}^{3} /\right.$ day) by 2020 . It is mostly used for direct non-potable use into wafer fabrication and electronics industries as well as in commercial and institutional complexes for air-conditioning cooling purposes via a separate distribution network [24]. Singapore is the first country to use potable reused water to meet the higher purity demands of wafer fabrication. The venture has been highly successful; the world's top three hard disk drive manufacturers are based in the city-state.

NEWater also supplements potable water supply via planned indirect potable use. It involves blending NEWater with raw reservoir water and conventional water treatment process to produce potable water [2]. In 2002, PUB started pumping 2 MGD of NEWater into reservoirs, before further treating the blended water for domestic use [21]. The amount blended in is not fixed but depends on local requirements.

In Singapore, the energy needed to treat water varies from about $0.2 \mathrm{kWh} / \mathrm{m}^{3}$ for water from local catchments or imported from Johor, Malaysia, to $1.0 \mathrm{kWh} / \mathrm{m}^{3}$ for NEWater and $3.6 \mathrm{kWh} / \mathrm{m}^{3}$ for desalination. The production of NEWater is thus more cost-effective than desalination. 
Singapore's experience with NEWater has been one of the most successful in the world. Before NEWater was launched, there were comprehensive information, communication and education efforts that included several sectors of the population: decision-makers, on long-term safety and reliability; the population at large, to address possible concerns; industries that could be potential consumers; and the media, who were taken on study trips to Orange County to see "water reuse in practice" [25]. In 2003, when the first two NEWater plants began producing water for public use, a NEWater Visitor Centre was also opened for educational purposes $[3,26]$.

An independent Forbes Research poll conducted at the end of 2002 found 98 percent public acceptance for NEWater, with 82 percent of respondents indicating that they would drink NEWater directly and another 16 percent responding that they would drink it after blending with reservoir water and further treatment [26]. One reason that NEWater is so well accepted among Singaporeans is because of its contribution towards self-sufficiency and national security [26], although this is not always understood [27].

\subsection{California, United States}

California has a land area of $423,970 \mathrm{~km}^{2}$ and a population of 39.25 million [28], making it the most populous state in the US. It had a total GDP of $\$ 2.46$ trillion [29] in 2015-the world's sixth-largest economy, according to Respaut [30]. The population is well educated, with 2 in 5 having attended college [31]. California has a long history of non-potable water reuse [32]. As in many other places, the need for additional sources of water arose from the rising demands of a growing population in the latter half of the twentieth century [33].

Following the growing use of farms using sewerage for irrigation called sewer farms, in the late nineteenth century, the city of Redondo Beach (in the greater Los Angeles area) voted against sewer outflow to the ocean, deciding instead to adapt the sewer farm model for reused water. By 1929, the city of Pomona (in Los Angeles County) began reusing water for lawn irrigation. The cost-efficiency of reused water became more evident when, in 1965, the city of Burbank (also in Los Angeles County) began using reused water for power plant cooling. In 1977, the Irvine Ranch Water District (based in Irvine, Orange County) began a large-scale residential landscape irrigation project via dual reticulation. In 1998, the Monterey Regional Water Pollution Control Agency initiated the first project that used tertiary-treated recycled water [34] to irrigate crops that were to be eaten raw [33]. (Monterey is about $500 \mathrm{~km}$ north of Los Angeles, on the California coast).

In Orange County, non-potable water reuse started in 1976, when Water Factory 21 started injecting highly treated reused water into a coastal aquifer as a barrier against seawater intrusion. In 2008, the Orange County Sanitation District and the Orange County Water District (the management agency for the Orange County groundwater basin) established the Groundwater Replenishment System [10]. Due to recurrent droughts and variability of the water supply, the district decided to use potable reused water as the primary source of supply for the groundwater basin.

The Groundwater Replenishment System has become the largest advanced water purification system for IPR in the world. Its production capacity increased from 264.98 MLD (70 MGD) in 2008 to 378.5 MLD (100 MGD) in 2015 of safe water. It plans to grow to a capacity of 492.1 MLD (130 MGD) by 2022 [35].

Public acceptance of potable reuse among Californians is relatively high. A January 2016 survey found that 42 percent were "very willing" to reused water in their day-to-day lives, while 41 percent were "somewhat willing". Notably, these numbers increased with additional information on the reuse process. Among those given this information, 89 percent were willing to use potable reused water [36]. According to the EPA 2017 [7], the public may favour IPR over DPR. However, conditions are site-specific. While both DPR and IPR have been deprecated as "toilet-to-tap" and "flush-to-faucet", more recent surveys indicate that the public understands that reused water can have even higher quality than current sources. This is reflected in the Pure Water San Diego project, where some public 
responses have called for the highly purified water to be used directly, rather than being released to the environment, where its quality could be degraded.

California has been very progressive regarding potable reuse. The California State Water Resources Control Board updated its water recycling policy in 2009. The objective was to increase the use of recycled water in the state over by at least $1.23 \mathrm{~km}^{3}$ /year (1 million acre-feet per year) over 2002 levels by 2020, and at least $2.46 \mathrm{~km}^{3} /$ year (2 million acre-feet/year) by 2030 [37].

The state has also adopted uniform water recycling regulations for IPR for groundwater recharge. In 2014, the State Water Board's Division of Drinking Water finalised groundwater replenishment regulations, which were incorporated into the state's regulations on recycled water. In 2017, the draft Surface Water Augmentation Regulations were released for public comments, and the final regulations were published in 2018 [38]. These regulations establish water quality requirements, the percentage of reused water that can be added to surface waters, and how long it must stay there before being treated again at a surface water treatment facility, before being provided as drinking water. It also includes engagement of the public in project development.

The state also intends to develop regulations for DPR. In 2016, an expert panel determined that it is feasible for the state to develop recycled water criteria for DPR. In October 2017, Assembly Bill 574 established a deadline of December 2023 for initial DPR regulations [39], after further research, expert consultation and public engagement have been carried out to ensure that they protect public health while increasing drinking water supplies $[37,40]$.

In addition, the State Water Resources Control Board's Water Recycling Funding Program provides grants to assist pubic agencies with the construction of pilot projects for potable reuse. The objective is to improve knowledge of current and new technologies for potable reuse [41]. In October 2018, President Trump signed the 'America's Water Infrastructure Act' (S.3021). Among other provisions, it will support significant investment in water infrastructure, including water recycling, treatment and technology [42].

\subsection{Queensland, Australia}

Queensland, covering 1.7 million $\mathrm{km}^{2}$, is the second-largest state in the Commonwealth of Australia. It has a population of about 4.94 million, and includes 428 major urban areas, localities and urban centres. Its capital is Brisbane.

In Australia, the Drinking Water Guidelines provide a framework for the management of drinking water quality. They also form the basis of the risk management framework adopted in the Australian Guidelines for Water Recycling [43]. Phase 1 of the Australian Guidelines for Water Recycling was published in 2006 by the National Resource Management Ministerial Council and the Environment Protection and Heritage Council. It provides guidance on managing the health and environmental risks associated with the use of recycled water for non-potable applications; it does not cover the development or management of potable water recycling schemes [3].

Phase 2 of the Australian Guidelines for Water Recycling consists of three modules that specifically address stormwater use, managed aquifer recharge and augmentation of drinking water supplies. The module on the augmentation of drinking water supplies provides risk management guidance for chemical and pathogenic contaminants, in addition to that provided in the Phase 1 guidelines [3]. As of June 2018, there were 168 reused water schemes in Queensland [44], up from 159 in 2015. These include the Bargara Recycled Water Scheme of the Bundaberg Regional Council, the Marlin Coast Sewerage Treatment Plant Recycled Water Scheme of the Cairns Regional Council, and the Cecil Plains STP Effluent Reuse Scheme of the Toowomba Regional Council.

The largest water recycling scheme, the Western Corridor Recycled Water Scheme in South East Queensland, was completed in December 2008. It was developed to provide an alternative water source amidst a protracted drought, but was stalled by public opposition [45]. The scheme was decommissioned but it can be recommissioned to produce potable water as a drought response measure if the region's combined dam levels fall below 40 percent [46]. 
In Toowoomba, Queensland, the second-largest inland city in Australia, a July 2006 public referendum, ostensibly held in response to increasing public opposition, resulted in rejection of potable water reuse by 62 percent of the voters [12]. The defeat has been attributed to several factors, including influential opinion leaders with unfavourable attitudes to drinking reused water [47], health concerns, and residents' concern for their city's image [12]. Referendum or not, the necessity for water supply augmentation remained; the demand for water in the city continued to exceed supply. In July 2008, it was announced that a pipeline would be constructed to link Toowoomba's Lake Cressbrook with Wivenhoe Dam [48]. This was Brisbane's main dam, to which the water from a major water reuse project, completed in 2008, would flow. The cost of the project was higher than what the recycling programme would have cost [49].

The rest of the paper is organised as follows. The following section details the methodology, where we explain what our sources of information are, how and why they were selected, and the types of analyses carried out. The last sections present the results, discussion and conclusions, and lessons learnt.

\section{Materials and Methods}

In this study, primary information was obtained by consolidating archival evidence: government officials' and water utility providers' statements and speeches, as well as newspaper articles, are used to explore public communications. Textual analysis was used to identify phrases and keywords expressing sentiments towards potable reuse and the enabling technologies. Every digitally accessible article that made mention of 'recycled drinking water' (or, for Singapore, 'NEWater') in The Straits Times, the Orange County Register, and the Queensland Courier-Mail from 1 January 2000 to 30 June 2018 was checked. The Los Angeles Times was also searched from 26 August 2007 to 31 August 2017 to complement information from the Orange County Register. These newspapers were selected because of their high readership.

The Straits Times, an English-language daily broadsheet established in 1845, is the most widely read English title in Singapore. In 2017, the newspaper's print and digital readership had a circulation of 383,600 , representing 28.8 percent reach on an average daily basis [50]. In 2016, 48 percent of its readers were professionals, managers, executives and businessmen [51].

The Los Angeles Times is the most widely read newspaper in California [52]. Like The Straits Times, it is a key communications pillar for the acceptance of water reuse technology. It was established in 1881 and is held in high regard. It has won numerous Pulitzer prizes [53]. In spring 2017, it had a readership of 2.36 million (113,000 of them in Orange County, immediately to the south of Los Angeles County).

The Orange County Register was founded in 1905. In 1985, it assumed its present name. At present, it is read by some 578,000 people daily and some 836,000 people on Sundays. It delivers 1.4 million printed newspapers per week. It has also won several Pulitzer prizes.

The Courier-Mail, a News Corp-owned tabloid, is among the most widely read newspapers in Queensland. In 2017, it had an average of 1.65 million readers [54]. In total, the newspaper is read by 69 percent of the people in Queensland. While its media kit does not provide a clear demographic breakdown of its readers, it explains that the newspaper is read by a broad audience, from professionals and influencers to Baby Boomers and affluent Queenslanders. 


\section{Results}

\subsection{Singapore}

\subsubsection{Framing of Technology in The Straits Times}

Without discernible exceptions, NEWater technology has been framed positively in The Straits Times. Allusions to technology comprise a significant proportion of coverage on the subject, rivalled only by the reason for potable reuse: self-sufficiency.

\section{State-of-the Art Technology}

The framing of technology has focused on its cutting-edge nature. One article calls Singapore's Deep Tunnel Sewerage System a "marvel of modern engineering" [55]. In other articles, it is referred as "incredible membrane technology" [56], call the recycling process a "major technological breakthrough" and laud "state-of-the-art water reclamation" [57]. This technology, The Straits Times emphasises, makes Singapore a global leader in the field. In August 2015, on the 50th anniversary of Singapore's independence, an editorial titled "Bottled Wonder" says that tiny Singapore-which, in the 1970s, sent a team to study water reuse projects in California and West Virginia [58] - has now "pioneered a technique superior to that of the US" [59]. An article in March 2017 notes that water managers in California are "adapting a technology refined in Singapore-the membrane bioreactor-to treat industrial reused water" [60].

\section{Thoroughness}

It is worth noting the historical significance of these comparisons to the US and California. Not long after Singapore's independence from its northern neighbour Malaysia in 1965, policymakers and urban planners, cognisant that the city-state could not risk dependence on imported water, took steps to create a water supply that would help Singapore become self-sufficient. However, Singapore's first foray into potable reuse, in the 1970s, fell short. In the years thereafter, Singapore sought advice from the US and sent a team to study water reclamation projects in Orange County and West Virginia [58]. That California is now learning from the city-state's technology highlights the rapid technological progress Singapore has made.

Also pertinent in the coverage of NEWater in The Straits Times is the painstaking approach that has been taken to recycle water [26]. News articles note, for instance, the "continual investments in and maintenance of water infrastructure" and that the "dual-mode desalination process took the Government years of research and testing to make it practical on a large scale" [61]. Readers are reminded that NEWater "undergoes many rounds of treatment with advanced membrane technologies and ultra-violet disinfection until it is potable" [62].

Dolnicar, Hurlimann and Nghiem [63] (p. 1293) assert that "providing information about treatment processes significantly increases stated likelihood to use". The clear focus on the thoroughness of the technological process of producing NEWater gives the Singapore public confidence that it is a safe product. Building on the success of NEWater in the preceding years, coverage of continuous technological improvements serves to maximise public confidence that Singapore remains up-to-date on maintaining a safe supply. This is reinforced in a 2009 interview with an editor-at-large and former editor of the paper, who explained that such information "helped readers understand that NEWater was being monitored and tested closely to make sure the quality of drinking water was always safe" [13].

\section{Focusing on the End-Product (Rather Than the Source Water)}

The end-product of the technological process is extremely clean water. A June 2016 article calls it "ultra-clean, high-grade NEWater" [64], while a March 2016 article laments that "Singapore residents continue to take a free flow of fresh, clean water for granted" [65]. The repetition of "clean" and 
other words in its semantic field bolsters the narrative that the end-product of the recycling process is completely safe for consumption.

\subsubsection{Framing of Potable Reused Water Technology by Leaders and Experts}

In Singapore, all aspects of water resources policy, management, governance and development have historically received support at the highest political level. This is why the city-state has been able to put in place one of the most comprehensive water and wastewater management systems in the world. Plans are that, by 2060, NEWater will be one of the most important sources of water for the city-state [26].

\section{Cutting-Edge}

In speeches by Singapore's political leaders, the cutting-edge nature of the technology used to produce NEWater is brought to the forefront, also emphasising its importance for self-sufficiency. At the official launch of NEWater in 2003, the then-Prime Minister called it a "judicious investment in infrastructure and effective use of technology are necessary to ensure an adequate and sustainable supply of good drinking water" [66]. In 2007, the now Prime Minister explained that NEWater is "produced using advanced membrane technologies" that "allows us to use each drop of water more than once". It will "multiply our effective supply of water"; and it is a "key pillar of our efforts to become self-sufficient in water." [67] At the Singapore International Water Week in July 2017, it was noted that Singapore has sensors to monitor its sewers as well: a system of over 40 voltaic volatile organic carbon ... sensors are placed in key nodes of our used water network to detect illegal discharges with more planned for the future.

\section{Cost-Effective}

At the official launch of NEWater in 2003, it was stated that "with advances in technology and improved energy efficiency, additional water sources are less costly than our projections five years ago" [66]. At the foundation-laying ceremony for a NEWater Factory, it was mentioned that the Public Utilities Board has been "able to bring down the cost of NEWater production through economies of scale, productivity gains, and more competitive membrane technologies" and that the public can expect "expect efficiency gains and a lower cost of production from this NEWater Factory" [68].

It had been noted before that "coupled with the decrease in membrane costs in recent years, we have been able to lower the price of NEWater from the original $\$ 1.30$ per cubic metre to $\$ 1.15$ per cubic metre" [67]. The technology used to produce reused drinking water is also presented as part of a cost-effective solution to meet water demand. Singapore continues to "keep abreast of new technologies and deploy them when they become cost-efficient and viable" [69].

In a statement to the Third United Nations Conference on Housing and Sustainable Urban Development, the Special Envoy to the Prime Minister expressed hope that "technologies and capabilities developed in Singapore can also help other cities facing similar water challenges" [70]. In 2010, it was noted that NEWater, besides solving water problems, has contributed towards the development of the water industry. Additionally, that "international recognition for Singapore's growth as a global hydrohub is best exemplified by the success of the Singapore International Water Week" [71]. In 2017, also during the Singapore International Water Week, it was highlighted that the city-state is a bellwether for the rest of the world when it comes to water.

Why Potable Reused Water?

However, the most notable feature of such speeches is the comprehensive explanation of why Singapore produces potable reused drinking water. This lays the groundwork for the necessity of investing in technology. Singapore's experience with reusing water is related to the broader imperative of self-sufficiency, survival and independence, framing water as a strategic security issue. 
This has been stressed in different occasions, for example, during the budget speech in 2017, when it was noted that "water sufficiency is matter of national survival" and that "members are well aware of how Mr. Lee Kuan Yew, Founding Prime Minister, strong interest over water since the Separation Agreement" [72]. At the 2016 World Cities Summit, NEWater was also framed as among the "investments" that have provided Singapore "with some security against the threats of climate change" [73].

The main views expressed in The Straits Times are summarised in Table 1. Figure 1, illustrating the language used in the context of potable water reuse, can be found after the table.

Table 1. Excerpts of newspaper articles from The Straits Times.

\begin{tabular}{|c|c|c|}
\hline Date & Title & Phrases \\
\hline 21 January 2001 & $\begin{array}{l}\text { In the pipeline: More recycled } \\
\text { water plants }\end{array}$ & $\begin{array}{l}\text { At the NEWater plant, water is treated by three processes: } \\
\text { microfiltration, reverse osmosis and ultraviolet filtration. }\end{array}$ \\
\hline 13 January 2001 & $\begin{array}{l}\text { Recycling to meet } 15 \% \text { of water needs } \\
\text { by } 2010\end{array}$ & $\begin{array}{l}\text { High costs had hampered recycling efforts. But no longer, now that new } \\
\text { technology is producing superior filters and membranes that make it } \\
\text { economical to recycle water on a large scale. }\end{array}$ \\
\hline 11 March 2003 & $\begin{array}{l}\text { Overseas firms thirst for NEWater's } \\
\text { ultra-pure success; Singapore's unique } \\
\text { combination of three refining processes } \\
\text { draws great interest from the US and } \\
\text { countries in the region }\end{array}$ & $\begin{array}{l}\text { This is a three-stage process that has won kudos worldwide. } \\
\text { It comprises filtering out elements - bacteria, viruses, solids - passing } \\
\text { the water through a semi-permeable membrane, and then exposing it to } \\
\text { ultraviolet light. Particles smaller than one-thousandth the thickness of } \\
\text { a human hair are removed. Only after that is the water sent to } \\
\text { reservoirs and companies. }\end{array}$ \\
\hline 28 January 2004 & SembCorp keen to build NEWater plant & $\begin{array}{l}\text { The company believes that it is 'well-positioned' to undertake the } \\
\text { project, given its technical, operational and management expertise in } \\
\text { water-recycling and wastewater treatment, he said. }\end{array}$ \\
\hline 22 March 2006 & $\begin{array}{l}\text { Water supplied by technology, } \\
\text { not nature }\end{array}$ & $\begin{array}{l}\text { Theoretically, the sky's the limit, as recycling ensures an 'almost infinite } \\
\text { supply' of water going around the same water chain. }\end{array}$ \\
\hline 6 June 2007 & $\begin{array}{l}\text { Race is on for green ways to treat water; } \\
\text { S'pore to play key role with industry } \\
\text { leaders wanting to learn from its success }\end{array}$ & $\begin{array}{l}\text { They were speaking on the second day of the fourth IWA Leading-Edge } \\
\text { Conference, which brings together more than } 300 \text { leaders in the } \\
\text { industry to showcase cutting-edge technologies and techniques. } \\
\text { These include more efficient membrane filters, reactors which harness } \\
\text { energy_-producing bacteria from waste water, and nanotechnology } \\
\text { systems which make treatment quicker and cheaper. }\end{array}$ \\
\hline 27 October 2007 & $\begin{array}{l}\text { NEWater-type plant ready in } \\
\text { Queensland }\end{array}$ & $\begin{array}{l}\text { As Singapore is one of a few countries in the world to employ water } \\
\text { reclamation technology, its water management model was the } \\
\text { inspiration behind Western Australia's massive water recycling project. }\end{array}$ \\
\hline $\begin{array}{l}\text { 1 September } \\
2011\end{array}$ & $\begin{array}{l}\text { S'pore hands over Johor waterworks; } \\
\text { Republic gives up right to draw water } \\
\text { from area on expiry of } 1961 \text { pact }\end{array}$ & $\begin{array}{c}\text { Yesterday's handover, though, has no impact on Singapore's ability to } \\
\text { secure enough water to meet its daily demand of } 380 \text { million gallons. } \\
\text { That is because the resulting shortfall has been more than made up for } \\
\text { by new reservoirs here and technological improvements in recycling } \\
\text { and desalinating water. }\end{array}$ \\
\hline 14 March 2013 & $\begin{array}{l}\text { Deep sewerage tunnel to extend to west } \\
\text { of S'pore; Work on underground } 18 \mathrm{~km} \\
\text { 'super highway', costing } \$ 3 \mathrm{~b} \text {, to start } \\
\text { in } 2016\end{array}$ & $\begin{array}{l}\text { At the recycling plants, the water goes through a series of screens to } \\
\text { remove debris, then a bioreactor where micro-organisms break down } \\
\text { impurities and organic waste. It also goes through two sedimentation } \\
\text { tanks where particles are allowed to settle. } \\
\text { What comes out will either be pumped } 5 \mathrm{~km} \text { out into the deep sea, or be } \\
\text { further purified to produce NEWater. }\end{array}$ \\
\hline 9 August 2015 & Bottled wonder & $\begin{array}{c}\text { Within six months, the PUB had pioneered a technique superior to that } \\
\text { of the US. Instead of using one or two methods, which was what the } \\
\text { Americans did, Singapore used three: microfiltration, reverse osmosis } \\
\text { and ultraviolet radiation. }\end{array}$ \\
\hline 22 March 2016 & The celebration of World Water Day & $\begin{array}{l}\text { Primitive water rationing has given way to technologically } \\
\text { produced NEWater. }\end{array}$ \\
\hline 23 March 2016 & $\begin{array}{l}\text { Water world: A look at } 5 \text { reservoirs } \\
\text { in Singapore }\end{array}$ & $\begin{array}{l}\text { NEWater is high-grade reclaimed water that undergoes many rounds of } \\
\text { treatment with advanced membrane technologies and ultra-violet } \\
\text { disinfection until it is potable. }\end{array}$ \\
\hline 23 June 2016 & $\begin{array}{l}\text { PUB calls tender for expansion of } \\
\text { Changi Water Reclamation Plant }\end{array}$ & $\begin{array}{l}\text { After expansion, it will continue to be compact and use advanced } \\
\text { technologies, said the PUB. }\end{array}$ \\
\hline 10 July 2016 & How Singapore will never go thirsty & $\begin{array}{l}\text { Singapore's DTSS is a marvel of modern engineering, allowing us to } \\
\text { efficiently convey a whole country's worth of sewage at minimal } \\
\text { expense. It is also a terrific example of how science and new technology, } \\
\text { combined with ingenuity and determination, have allowed us to greatly } \\
\text { reduce the cost of water husbandry. }\end{array}$ \\
\hline
\end{tabular}


Table 1. Cont.

\begin{tabular}{|c|c|c|}
\hline Date & Title & Phrases \\
\hline $\begin{array}{l}18 \text { September } \\
2016\end{array}$ & What's next after NEWater & $\begin{array}{l}\text { Welcome to the incredible world of membrane technology. It works } \\
\text { because the filter does the job at the molecular level, separating actual } \\
\text { particles of water from the rest. }\end{array}$ \\
\hline 19 January 2017 & $\$ 170 \mathrm{~m}$ fifth NEWater plant launched & $\begin{array}{l}\text { 'While PUB has managed its costs over the year through improvements } \\
\text { in productivity and technology, much of the incremental improvements } \\
\text { have already been reaped,' he said. }\end{array}$ \\
\hline 2 March 2017 & Securing Singapore's water future & $\begin{array}{c}\text { Since then, water technology has progressed steadily. PUB itself } \\
\text { invested in R\&D. This resulted in NEWater, which was much cheaper } \\
\text { than desalination. }\end{array}$ \\
\hline 2 March 2017 & Securing Singapore's water future & $\begin{array}{l}\text { Technologically, Singapore has squeezed everything it can from the } \\
\text { current water processing technology. }\end{array}$ \\
\hline 12 March 2017 & $\begin{array}{l}\text { Keeping Singapore's taps flowing in the } \\
\text { quest for a robust water supply }\end{array}$ & $\begin{array}{l}\text { In California, water managers are adapting a technology refined in } \\
\text { Singapore-the membrane bioreactor-to treat industrial waste water } \\
\text { and use the treated water to directly replenish the water-stressed state's } \\
\text { freshwater aquifers instead of discharging it into the sea. }\end{array}$ \\
\hline 12 March 2017 & $\begin{array}{l}\text { Feeling the heat after drying up of } \\
\text { 'water is precious' message }\end{array}$ & $\begin{array}{l}\text { Thankfully, Singapore pressed ahead, not only with desalination-the } \\
\text { first plant to purify sea water was embarked on soon afterwards and } \\
\text { completed in 2005-but also by harnessing the technology to reclaim } \\
\text { used water in } 2003 .\end{array}$ \\
\hline 23 June 2017 & $\begin{array}{l}\text { PUB calls tender for expansion of } \\
\text { Changi Water Reclamation Plant }\end{array}$ & $\begin{array}{c}\text { Commissioned in 2008, Changi WRP (Water Reclamation Plant) is one } \\
\text { of the largest and most advanced water reclamation facilities in the } \\
\text { world. It treats about half of Singapore's used water, and produces } \\
\text { treated effluent which is used to produce the ultra-clean, } \\
\text { high-grade NEWater. }\end{array}$ \\
\hline 18 July 2017 & $\begin{array}{l}\text { Singapore to beef up research into water } \\
\text { technologies with international partners }\end{array}$ & $\begin{array}{l}\text { The other agreement, between PUB and Western Australia's Water } \\
\text { Corporation, will boost collaboration in the fields of urban water } \\
\text { supply, waste water management and innovation. }\end{array}$ \\
\hline 16 January 2018 & $\begin{array}{l}\text { PUB sets aside up to } \$ 30 \mathrm{~m} \text { for water } \\
\text { treatment solutions }\end{array}$ & $\begin{array}{c}\text { Announcing this yesterday, it invited industry technology providers } \\
\text { and researchers to develop solutions that will improve the effectiveness } \\
\text { of Singapore's water treatment processes and operations, and ensure } \\
\text { water sustainability. }\end{array}$ \\
\hline
\end{tabular}

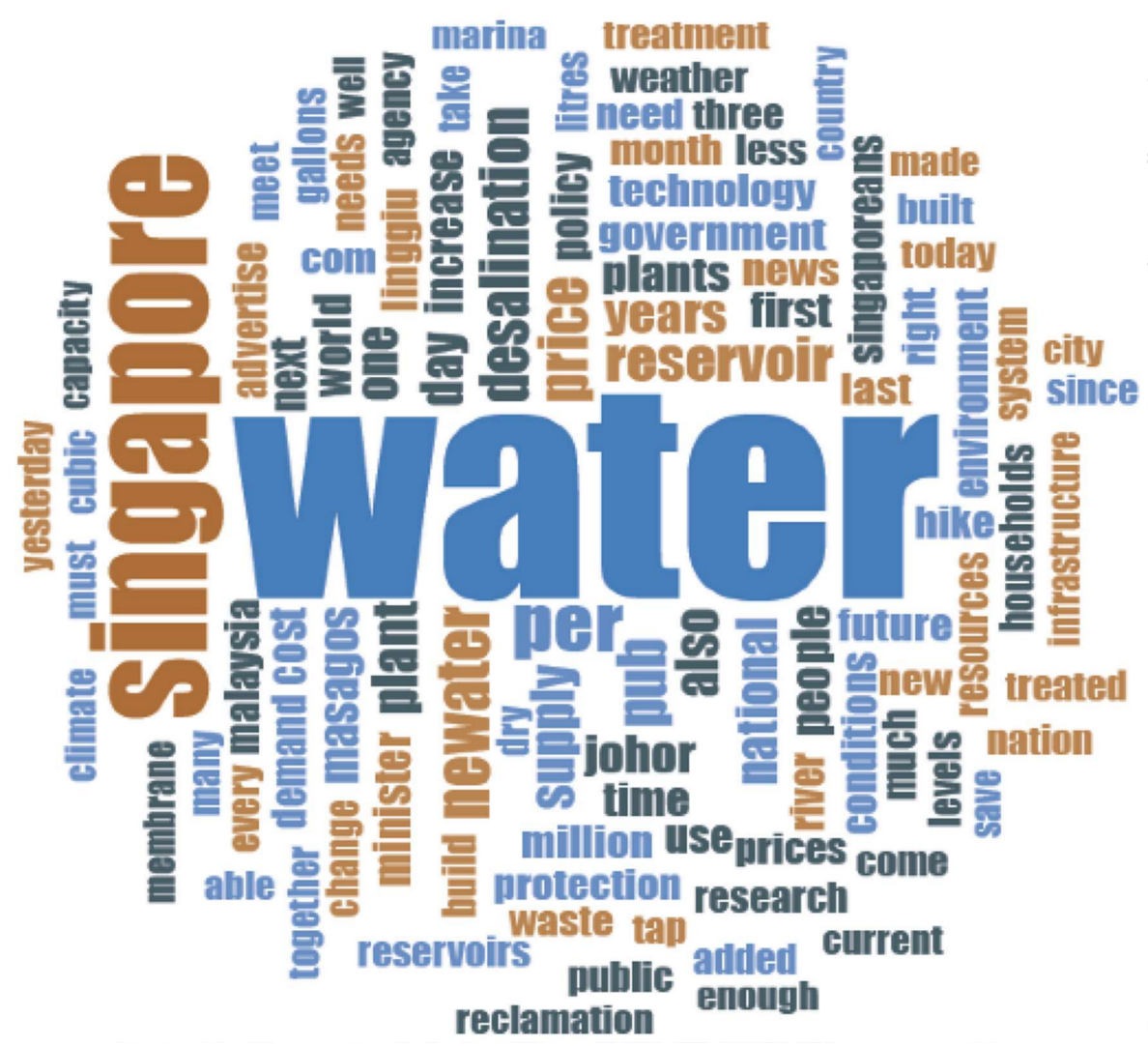

Figure 1. The Straits Times: terms associated with potable water reuse. 
Figure 1 is a visual representation of the importance the media articles give to reused water. The word that appears most frequently in the context of NEWater is 'water', followed by 'Singapore'. Frequently used are words from the semantic field of technological processes relating to water reuse that have become part of the daily vocabulary, such as 'NEWater', 'reclamation', 'desalination', 'research', 'treatment', 'technology' (including 'membrane'), 'marina' (the 15th reservoir, located in one of Singapore's most urbanised areas), 'infrastructure' (including 'reservoir'). This emphasises the thoroughness of the treatment processes.

The second-most common word, 'Singapore' (along with the less frequent 'Singaporeans'), indicates that reused water is framed in national terms, as a means of self-sufficiency. This is reinforced by frequent instances of 'Malaysia', 'Johor' and 'Linggiu' (the name of the reservoir where water is stored in Johor), which can also be taken to refer to the question of national self-sufficiency.

\subsection{California}

\subsubsection{Framing of Technology in the Los Angeles Times and the Orange County Register}

Overall, the coverage of this topic in these two Southern California newspapers is fairly similar, with both emphasising the technology used to produce potable reused water, as in The Straits Times. However, the newspapers pay less attention to the subject than The Straits Times.

\section{Cleanliness of End-Product}

Articles on the technology behind the potable reuse of water in the Los Angeles Times may be divided into two prongs: the cleanliness of the final product, and its unpalatable origins.

The thoroughness of the recycling process in producing clean potable reused water is communicated often to the Los Angeles Times readership. One article notes that the "end result of this 'toilet to tap' process is a substance that is cleaner than most bottled waters, and is intended for human consumption" [74]. Another invokes third-person expertise to vouch for the integrity of potable reused water: "engineers say there's no question the product is clean enough to drink" [75]. The traction of positive public communications from 'experts' is consistent with the assertion that consumers may be "taking the lead from the acknowledged experts" and "take on similar dispositions" [76].

The theme of cleanliness carries on in another article, which says that the treated water has a "purity indistinguishable from unpolluted rainwater" [77]. Another says that the process is "so advanced the recycled supplies are cleaner than what comes out of a nearby creek" [78]. On boosting water levels in the iconic Lake Mission Viejo with potable reused water, one article says that the "'advanced purified water' would be so clean that it could improve the lake's overall water quality" [74].

\section{Cost-Effectiveness}

Hand in hand with the theme of cleanliness is the theme of the cost advantages of water reuse, thanks to advanced technology. One article notes that "steadily advancing technology may allow the MWD (Metropolitan Water District) to purify water cheaply and efficiently" [79]. Another introduces the cost of reused water by noting it will "cost the county as little as USD 1200 per acre-foot, and the marginal cost of water obtained through conservation and efficiency measures could be as little as $\$ 150$, according to a 2012 estimate by the Pacific Institute" [80]. Comparing the process to alternatives, an article notes that the technology enabling reused potable water is "far cheaper than ocean desalination" [81], while another warns that "desalination typically is the most expensive water a community can buy" [81]. Another article notes that cost-efficient technology will result in an "additional benefit-lower bills" [82]. In a somewhat different light, an article in the Orange County Register highlights that the cost of reused drinking water is in line with treated water from other sources. 
This focus on the tangible benefits of the technology raises its appeal. There is a clear-cut benefit to households, fostering the perception that the technology is to benefit the community.

Aversion

While attitudes towards the technological process are largely positive, signs of aversion to the process are not absent. The aversion to the water treatment process is centred not on the treatment, but on the source water. One article notes an official insisting that "turning sewage into tap water was not part of the plan" [77], and another highlights reassurance that "in this state no recycling program puts cleaned-up sewage directly into the water supply" [79]. The process is deprecated in a number of articles as 'toilet to tap', as in the passage, "Angelenos, it seemed, were too good to drink perfectly safe recycled water-dismissed as 'toilet to tap"" [83]. In one article, a member of the public is quoted asserting that he "would not drink water that has been recycled through the toilet to tap process" [84].

In defence of the process, one article reminds readers that "two decades and countless billions of gallons of safe and clean drinking water" have been jeopardised "because of demagoguery over a smart-water stewardship program that became known, quite inaccurately, as "toilet to tap" [79]. Another reminds readers that "all water has been recycled, toilet to tap, by nature. If you feel a yuck factor, get over it" [85].

\subsubsection{Framing of Potable Reused Water Technology by Leaders and Experts}

Cutting-Edge Technology

During a Legislative Hearing, the general manager of the Orange County Sanitation District noted that the Groundwater Replenishment System "is the world's largest advanced water purification system"; he also used the phrases "three-step advanced process", "sophisticated process", and "three-step advanced treatment system" [86]. The clear focus on the advanced nature of the technology inspires confidence among the public. At PUB Spotlight 2017 in Singapore, the general manager of the Orange County Water District noted that the tradition of innovation in the district has contributed to the confidence of the regulators and the public.

Safe

This advanced technology produces drinkable purified water: "high-quality water that exceeds all state and federal drinking water standards" [86]. It is described as the best available water, with higher quality than water from other existing sources. In the Water Recycling Acceleration Act of 2015 (H.R. 2993), water quality is an important consideration [87]. In a PBS NewsHour interview in 2008, the general manager of the Orange County Water District said that the treatment will "remove any bacteria, protozoa, or suspended solids that are in the water"; in comparison, the present (non-recycled) water supply "isn't clean and pure now" [88].

Tables 2 and 3 present the main arguments of selected articles from the Los Angeles Times and the Orange County Register, respectively. Figures 2 and 3 illustrating the language used in the context of potable water reuse can be found after the tables.

As in the coverage in Singapore, location words-'California' and 'Los Angeles'-take centre stage among the key words. This may reflect to readers that water recycling is allied with the community's interests. This sentiment is compounded by the frequency of the word 'community' in the Orange County Register. Water recycling is framed as a necessary step in light of water shortages arising from environmental crises; words such as 'drought', 'climate', and 'supply' are used frequently. Discussions also refer to topics related to infrastructure (dams, reservoirs, tunnels), sources of water (groundwater), wastewater and recycled water, water rights, the delta and the importance of the environment, and government plans and funding, indicating the importance of the state government support. 
Table 2. Excerpts of selected newspaper articles in the Los Angeles Times.

\begin{tabular}{|c|c|c|}
\hline Date & Title & Phrases \\
\hline 26 August 2007 & Revisiting 'toilet to tap' & $\begin{array}{l}\text { This is because modern water-purification technology is } \\
\text { considered totally reliable. }\end{array}$ \\
\hline 18 May 2008 & Tapping into the future & $\begin{array}{l}\text { Recycling technology has improved. Orange County has } \\
\text { already started recycling water for indirect potable reuse. }\end{array}$ \\
\hline 4 February 2014 & $\begin{array}{l}\text { Don't gag: It's time for L.A. to embrace } \\
\text { 'toilet to tap' water }\end{array}$ & $\begin{array}{l}\text { Our neighbors have invested in the technology. Orange } \\
\text { County reclaims } 70 \text { million gallons of sewage daily, with plans } \\
\text { to treat even more. }\end{array}$ \\
\hline 24 May 2015 & $\begin{array}{l}\text { Turning sewage into drinking water gains } \\
\text { appeal as drought lingers }\end{array}$ & $\begin{array}{l}\text { In potable reuse systems, effluent from a wastewater } \\
\text { treatment plant is sent to an advanced treatment facility, } \\
\text { where it undergoes a three-step purification process. }\end{array}$ \\
\hline 22 September 2015 & $\begin{array}{l}\text { Metropolitan Water District aims to build } \\
\text { plant to recycle sewage into drinking water }\end{array}$ & $\begin{array}{l}\text { The plan would thrust Los Angeles County to the forefront of } \\
\text { a small but growing number of areas embracing 'toilet to tap' } \\
\text { technology to meet the water needs of their residents. }\end{array}$ \\
\hline 22 September 2015 & $\begin{array}{l}\text { California seeks to build one of world's } \\
\text { largest recycled water programs }\end{array}$ & $\begin{array}{l}\text { Potable reuse systems, on the other hand, use a variety of } \\
\text { methods to purify water that has already been processed at } \\
\text { a sewage treatment facility. The end result of this "toilet to tap" } \\
\text { process is a substance that is cleaner than most bottled waters, } \\
\text { and is intended for human consumption. }\end{array}$ \\
\hline 23 September 2015 & $\begin{array}{l}\text { EDITORIAL: MWD's water recycling plan } \\
\text { is a good one, but don't call it 'toilet to tap' }\end{array}$ & $\begin{array}{l}\text { Steadily advancing technology may allow the MWD to purify } \\
\text { water cheaply and efficiently on the surface. }\end{array}$ \\
\hline 3 November 2015 & $\begin{array}{l}\text { Planned purification plant would eliminate } \\
\text { need for imported water, officials say }\end{array}$ & $\begin{array}{l}\text { It would take water from a nearby sewage treatment facility } \\
\text { and, using advanced procedures such as reverse osmosis, } \\
\text { purify that water to meet or exceed drinking water standards. }\end{array}$ \\
\hline 19 May 2017 & $\begin{array}{l}\text { COLUMN: As political pressure for } \\
\text { approval intensifies, the case for a big } \\
\text { desalination plant remains cloudy }\end{array}$ & $\begin{array}{l}\text { Recycled water would cost the county as little as } \$ 1200 \\
\text { per acre-foot }\end{array}$ \\
\hline
\end{tabular}

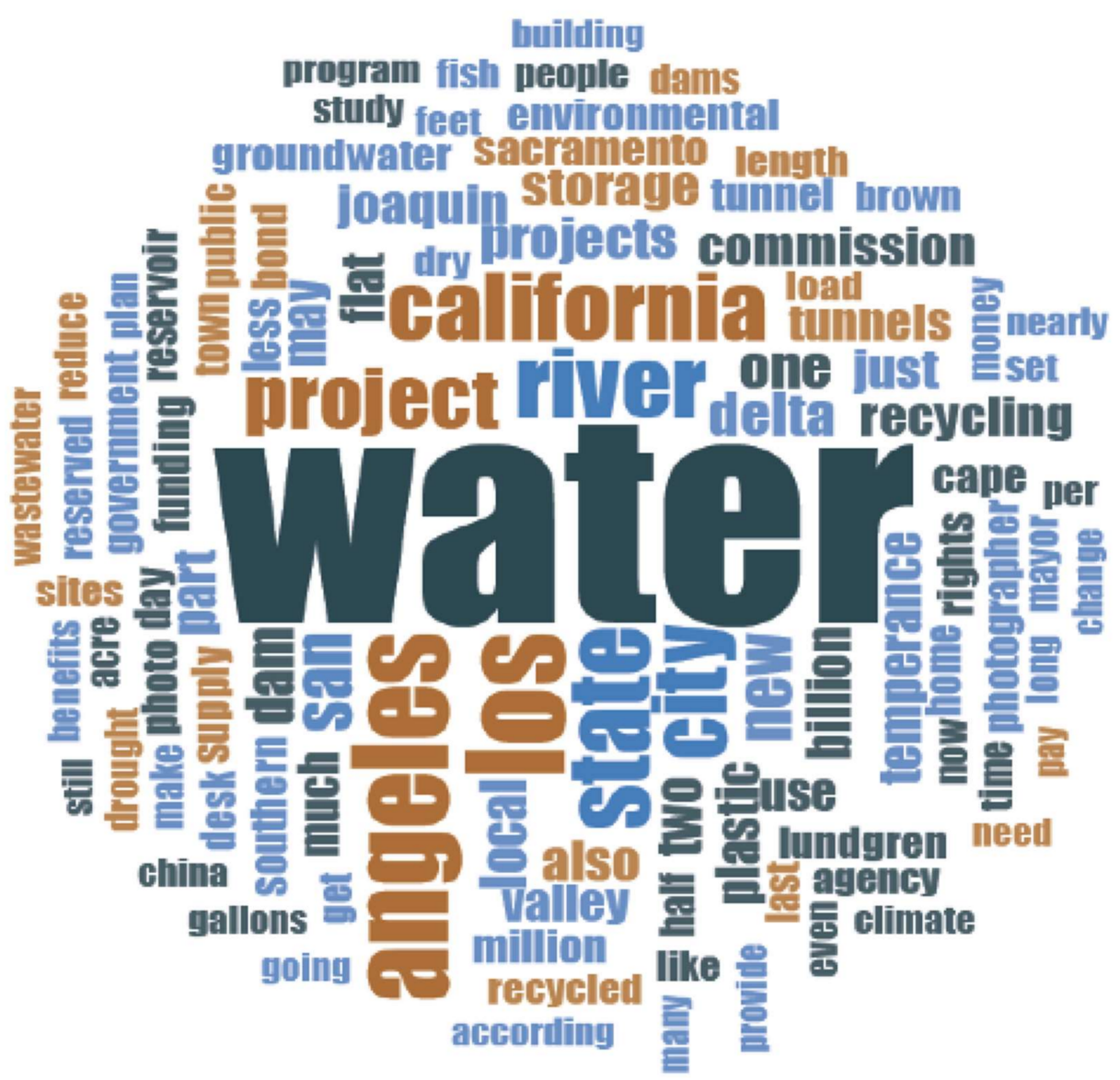

Figure 2. Los Angeles Times: terms associated with potable water reuse. 
Table 3. Excerpts of selected newspaper articles in the Orange County Register.

\begin{tabular}{|c|c|c|}
\hline Date & Title & Phrases \\
\hline 2 March 2000 & $\begin{array}{l}\text { Water plan sinking as cost climbs; } \\
\text { COUNTY: Price estimate for } \\
\text { a sewage-purification system rises } \\
\text { to } \$ 600 \text { million. }\end{array}$ & $\begin{array}{l}\text { The water district and the Orange County Sanitation District have } \\
\text { jointly studied the "toilet to tap" idea since } 1997 \text { as a way to meet } \\
\text { growing demand, reduce the need for imported water and avoid } \\
\text { building an ocean sewage outfall. }\end{array}$ \\
\hline 30 September 2000 & $\begin{array}{l}\text { Reclaimed water gets into } \\
\text { Newport supply }\end{array}$ & $\begin{array}{l}\text { Reclaimed water begins as sewage that is filtered and treated at } \\
\text { a waste-water treatment plant, Wildermuth said. The reclaimed water } \\
\text { that entered the drinking-water system had been treated again to } \\
\text { remove any remaining bacteria and viruses. That process includes } \\
\text { adding chlorine and other cleansing chemicals and filtering the water } \\
\text { through charcoal and sand, Wildermuth said. }\end{array}$ \\
\hline 8 August 2002 & $\begin{array}{l}\text { City's reclaimed water making its } \\
\text { way indoors }\end{array}$ & $\begin{array}{l}\text { Recycled water, by the way, is the water that drains from your showers, } \\
\text { sinks and toilets. It is not storm drain water or runoff. } \\
\text { The sewage is sent to the district reclamation plant on Michelson, } \\
\text { where it is filtered, disinfected and treated with microscopic organisms } \\
\text { that consume bacteria. } \\
\text { It takes the district } 12 \text { to } 15 \mathrm{~h} \text { to treat the water and redistribute it. } \\
\text { About } 15 \text { million gallons of reclaimed water are produced each day-20 } \\
\text { percent of IRWD's total water supply. }\end{array}$ \\
\hline 17 June 2005 & $\begin{array}{l}\text { Water pipeline project to impact } \\
\text { traffic; The } \$ 4.5 \text { million water } \\
\text { district project will connect } \\
\text { domestic water and recycled water } \\
\text { pipelines }\end{array}$ & $\begin{array}{l}\text { The } \$ 4.5 \text { million project will connect domestic water and recycled water } \\
\text { pipelines between the communities, which will increase the Santa } \\
\text { Margarita Water District's efficiency in transporting the water, said Dan } \\
\text { Ferons, the district's chief engineer. }\end{array}$ \\
\hline 4 December 2007 & A toast to recycled sewage & $\begin{array}{l}\text { Also, the cost of the usable water the system produces-about } \$ 500 \text { per } \\
\text { acre-foot, which is about } 325,000 \text { gallons-is in line with treated water } \\
\text { we buy from other sources. }\end{array}$ \\
\hline 9 January 2014 & $\begin{array}{l}\text { Basin at Boeing site to buoy water } \\
\text { recycling system }\end{array}$ & $\begin{array}{l}\text { The water goes through a series of treatments, ending when it is } \\
\text { pumped into basins in Anaheim where it percolates into the } \\
\text { groundwater aquifer. }\end{array}$ \\
\hline 24 April 2014 & $\begin{array}{l}\text { Anaheim's Water Sustainability } \\
\text { Campus helps fight the effects } \\
\text { of drought }\end{array}$ & $\begin{array}{l}\text { Large machines use ozone, membrane filters and ultraviolet treatments } \\
\text { to kill off bacteria and recycle waste generated throughout Anaheim to } \\
\text { produce 50,000 gallons of water each day to irrigate the landscaping at } \\
\text { City Hall. }\end{array}$ \\
\hline 24 February 2015 & $\begin{array}{l}\text { Yes, you can drink it-and you } \\
\text { probably are: O.C. toilet-to-tap } \\
\text { recycled water program } \\
\text { is expanding }\end{array}$ & $\begin{array}{l}\text { Second, the water goes through reverse osmosis, where it is forced } \\
\text { through fine, bundled membranes to remove minerals, chemicals, } \\
\text { viruses and pharmaceuticals. This is the heart of the OCWD's } \\
\text { treatment technology. } \\
\text { The facility takes treated sewer water from the Orange County } \\
\text { Sanitation District destined for the Pacific Ocean and runs it through } \\
\text { a three-part treatment. }\end{array}$ \\
\hline 15 June 2015 & $\begin{array}{l}\text { Disney, Irvine Co. top the list of } \\
\text { biggest water users in Orange } \\
\text { County: See who else joins them }\end{array}$ & $\begin{array}{l}\text { There, the water undergoes advanced treatment, resulting in } 70 \text { million } \\
\text { gallons of purified } \mathrm{H}_{2} \mathrm{O} \text { being injected into the ground to refresh } \\
\text { the aquifer. }\end{array}$ \\
\hline 17 June 2015 & $\begin{array}{l}\text { OC Watchdog: How much are } \\
\text { colleges such as UC Irvine, Cal } \\
\text { State Fullerton spending on water? }\end{array}$ & $\begin{array}{c}\text { Soka, in Aliso Viejo, is a young campus, relatively speaking, } \\
\text { which allows it to take advantage of newer technologies. Recycled } \\
\text { waste water is used in all its landscaping, which requires an extensive } \\
\text { double-piping system. }\end{array}$ \\
\hline 15 April 2016 & $\begin{array}{l}\text { Lake Mission Viejo to test the } \\
\text { waters by using treated sewer } \\
\text { water }\end{array}$ & $\begin{array}{l}\text { There, sewage water is treated in a process that includes filtration tanks, } \\
\text { reverse osmosis and ultraviolet light, making it safe enough to supply } \\
\text { underground drinking water in north and central Orange County. }\end{array}$ \\
\hline 14 October 2016 & $\begin{array}{l}\text { Lake Mission Viejo ready for } \\
\text { recycled water }\end{array}$ & $\begin{array}{l}\text { The treatment method is similar to one used by the Orange County } \\
\text { Water District's Groundwater Replenishment System facility in } \\
\text { Fountain Valley. There, wastewater is treated in a process that includes } \\
\text { filtration tanks, reverse osmosis and ultraviolet light, making it safe } \\
\text { enough to supply underground aquifers in north and central } \\
\text { Orange County. }\end{array}$ \\
\hline 21 June 2017 & $\begin{array}{l}\text { Hollywood residents get the } \\
\text { chance to drink purified toilet } \\
\text { water from Orange County }\end{array}$ & $\begin{array}{l}\text { Now, OCWD says their treatment is so advanced it can deliver the } \\
\text { product directly to homes and businesses. }\end{array}$ \\
\hline 19 February 2018 & $\begin{array}{l}\text { From waste to taste: Orange } \\
\text { County sets recycled water } \\
\text { world record }\end{array}$ & $\begin{array}{l}\text { The replenishment system aims to grow to a capacity of } 130 \text { million } \\
\text { gallons daily. The water, previously pumped into the ocean, not only } \\
\text { helps to sustain the county groundwater basin, but it creates a barrier to } \\
\text { prevent seawater intrusion into the water supply. It also greatly reduces } \\
\text { the county's need for more expensive imported water and uses less } \\
\text { energy than imported or desalinated water, according to the } \\
\text { water district. }\end{array}$ \\
\hline
\end{tabular}




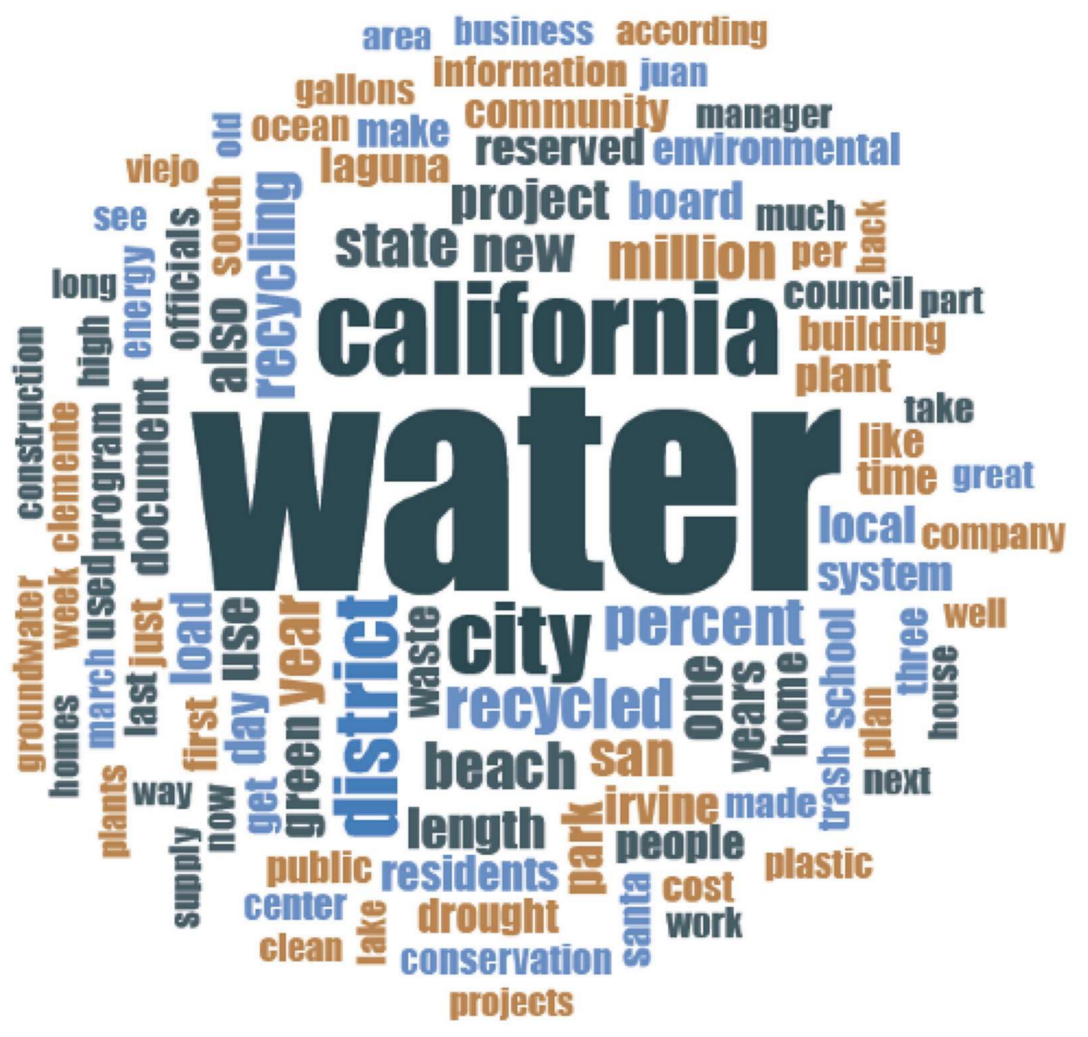

Figure 3. Orange County Register: terms associated with potable water reuse.

Not surprisingly, 'water' is also the focus of media articles in Orange County Register, followed by 'California'. Emphasis is also placed on water supply and the water sources (e.g., 'groundwater'), 'infrastructure', 'conservation', 'energy', importance of the 'environment', government 'programs', role of the 'communities', 'information', 'drought' events.

\subsection{Australia}

\subsubsection{Framing of Technology in The Courier-Mail}

Allusions to the technology behind reused water are infrequent in The Courier-Mail. In the rare instances that it is mentioned, articles tend to centre on its high cost. One article notes that the "previous Labor government ran up a huge debt attempting to drought-proof Queensland with large-scale projects" [89]. Technology, here, seems to have shifted into the realm of partisan politics. Other articles refer to a " $\$ 2$ billion recycled water pipeline" [90] and that "residents are already paying through the nose for this water" [91].

Scepticism of the Integrity of the Technology

Many articles question the integrity of the technology used. An outlier notes that the technology is "state-of-the-art" [91], but a more typical one cites "concerns about 'rogue' recycled water test results" [92]; and other asserts that "tests of samples produced out of the Western Corridor Recycled Water project had detected bromodichloromethane" and that "other substances found in the recycled water samples included cadmium, paracetamol and insecticide" [93].

Focusing on the Source Water

In contrast to The Straits Times and the Los Angeles Times, the framing of reused drinking water in The Courier-Mail tends to centre on aversion to the source water. One article describes a "radical scheme to turn sewage into drinking water in 2007" [94]; another refers to the "debate on drinking 
treated effluent" and claims that "at least 30 Queensland towns are unwittingly drinking recycled sewage" [95].

Aversion to reused water gave rise to the negative referendum outcome in Toowoomba. Centred on the source water, this aversion reflected that a "major barrier to reuse of wastewater is psychological not technical" special interest groups include "those opposed to the concept of drinking reused water such as 'Citizens 76 against drinking sewage'" $[12,96,97]$. Consistent with the assertion of the need to "provide the public with factual information and experience to increase their acceptance and improve their attitudes" [98], the absence of significant information on the technology surrounding potable reused water in a newspaper so widely read is noteworthy. Given the increased likelihood of public acceptance when the public is kept informed, the absence of educational coverage of the process that produces potable reused water may be a key underpinning of the aversion that arose in parts of Queensland.

\subsubsection{Framing of Potable Reused Water Technology by Leaders and Experts}

\section{Drought}

In discussions of potable reused water, Queensland's experts stress the value of reuse in augmenting water supply during periods of drought. In 2015, the Minister of Energy and Water Supply remarked that the "Western Corridor Recycled Water Scheme and the Gold Coast Desalination Plant form an important part of South East Queensland's climate resilient water supply" [97]. Two years prior, the Minister of Energy and Water Supply noted that the Western Corridor Recycled Water Scheme "can continue to be used to provide a drought response when water levels fall below critical levels" [98]. In a public briefing, the Queensland Conservation Council's Rivers Project Officer noted that it was "feasible to rely on the Tugun desalination plant and the Western Corridor Recycled [Water] Scheme in conjunction with robust dam management strategies, as in what we achieved during the height of the drought" [99].

\section{Production Capacity}

This is possible due to the high production capacity of the water recycling technology. The project is described as having the capacity to "supply approximately 182 million litres from October 2008 and approximately 232 million litres for South East Queensland by December 2008" [100].

\section{Farming}

To a question on whether reused water would be used to support agriculture in the Fassifern and Lockyer Valleys, the Minister of Energy and Water Utilities responded that "SEQ Water Grid Manager and the Queensland Water Commission are continuing dialogue with the Lockyer Water Users Forum for the supply of purified recycled water to the farming community" [101].

\section{Industrial Users}

The importance of reused water to industry in Queensland is often pointed out. In a submission to the State Development, Infrastructure and Industry Committee Inquiry into Queensland Audit Office Report to Parliament, chief executive officer of SEQ Catchments, noted that " 5600 million litres of recycled water were produced with the all the recycled water being consumed by industrial users", and " 3 advanced water treatment plants producing purified recycling water" [102]. To a question on the strategies in place to conserve Queensland's water resources, the minister of natural resources, mines and water responded that the government has "agreed to provide an initial \$20 million to fast track the Western Corridor Recycling Project", which, he added, "will involve the use of recycled water to supply the Swanbank and Tarong power stations and potentially other industrial users" [103]. 
Safe

A number of experts in Queensland have taken pains to underscore the cleanliness of potable reused water. The Minister of Environment, for example, noted that the technology is "sophisticated and provides very highly treated water". The Minister of Trade noted that, in addition to "strict microbiological requirements", the "chemical quality of recycled water used for food production must also meet the requirements of the Australian Water Quality Guidelines for Fresh and Marine Waters". He added that the Queensland Water Strategy "requires the preparation of guidelines detailing recycled water quality requirements for all types of use" [104].

This was emphasised by the Deputy Premier and Minister of Infrastructure and Planning, who noted that the "water produced is tested for some 200 parameters to ensure the meeting of water quality standards" and that the parameters are "determined by a risk assessment overseen by Queensland Health". He added that "on-line monitoring determines if the sensitive waste water treatment process is operating effectively and prevents supply to recycled water scheme if water quality outside of acceptable limits is detected" [105].

Large Investment

Producing potable reused water is framed as a significant investment. The deputy premier, treasurer and minister of infrastructure noted the spending of " $\$ 100 \mathrm{M}$ for an initial order of pipes for the first stage of the Western Corridor Recycled Water Scheme" [106]. The Deputy Premier and Minister of Infrastructure and Planning explained that the " $\$ 9$ billion South East Queensland Water Grid includes the Southern Regional Water Pipeline and the Gold Coast Desalination Plant which are due to finish construction at the end of 2008" [107]. The Premier and Treasurer said that the "Western Corridor will benefit from a $\$ 861$ million investment in water across the region, particularly key recycled water schemes and bulk water distribution projects" [108]. The Minister of the Environment, Local Government and Planning noted that " $\$ 21.8$ million has been allocated to water recycling subsidies, plus an additional $\$ 1.4$ million on advanced treatment technologies that support recycling" [109].

There is little doubt that allusions to the significant levels of capital put into water reuse inspires confidence in members of the public. The message is clear: this is a large-scale project, and a significant amount of attention is being paid to it.

\section{Lack of Support}

In contrast with the framing of technology for potable reused water by Singapore's leaders and experts, there is little unity in the messages presented by Queensland's politicians and experts.

Many are sceptical about the use of technology to produce potable reused water because of its cost. In a 2002 letter to the Premier of Queensland, the Prime Minister noted that "the pumping of treated effluent from Brisbane to the Lockyer Valley and Darling Downs appears to have very high costs that are largely for private benefit" [110]. A letter from the chief executive officer of the Queensland Farmers Federation noted that the Queensland Audit Office "finds that the cost of water supply from the project was not 'balanced against a realistic assessment of benefits'" [111]. At a public hearing, a Member of the Parliament of Burleigh noted that water recycling plants "are very expensive to operate because of the force of water. You have to push through the membranes."

This was echoed by the deputy director-general of the Water Supply Division of the Department of Energy and Water Supply at a public inquiry in 2013, where he noted that reused water plants, like desalination plants, are "quite expensive sources of water. I am just not sure how the economics would stack up" [112].

The Deputy Premier and Minister of Infrastructure and Planning called such criticisms of potable reused water "opportunistic political grandstanding by the Opposition" which "culminates in their loose, roughly cobbled together water policy, which would deliver less water, yet cost more for the 
residents of South East Queensland". He charged that their "input is constrained to cheap political point-scoring by vehemently opposing the SEQ Water Grid every step of the way" [113].

Table 4 presents an excerpt of newspaper articles from The Courier-Mail. Figure 4 is a visual representation of language related to potable water reuse in the newspaper.

Table 4. Excerpts of selected newspaper articles in The Courier-Mail.

\begin{tabular}{|c|c|c|}
\hline Date & Title & Phrases \\
\hline 6 June 2000 & City budget goes to water & $\begin{array}{l}\text { A multimillion-dollar boost for Brisbane's waterways and sewerage infrastructure } \\
\text { will be announced in tomorrow's City Council budget. }\end{array}$ \\
\hline 20 June 2000 & $\begin{array}{l}\text { City drinks up as wastewater } \\
\text { flows to dams }\end{array}$ & $\begin{array}{l}\text { BRISBANE residents are drinking thousands of cubic metres of diluted treated } \\
\text { effluent each day as nearby towns discharge their wastewater upstream of the } \\
\text { city's dams. }\end{array}$ \\
\hline 10 July 2000 & Wastewater alert hits schools & $\begin{array}{l}\text { SEVERAL Queensland school ovals are being irrigated by "extremely dangerous" } \\
\text { treated effluent, according to a departmental document. } \\
\text { The Department of Natural Resources document obtained under the Freedom of } \\
\text { Information Act has slammed a number of school water recycling schemes as } \\
\text { "unsustainable" and in urgent need of review. }\end{array}$ \\
\hline $\begin{array}{l}20 \text { November } \\
2000\end{array}$ & Sewage key to drinking water & $\begin{array}{l}\text { QUEENSLAND'S future drinking water could come partly from treated, diluted } \\
\text { sewage effluent. } \\
\text { Treating wastewater and mixing it with river, dam or aquifer waters and then } \\
\text { re-treating it and returning it to the mains is an option in a draft strategy released } \\
\text { yesterday. }\end{array}$ \\
\hline $\begin{array}{l}27 \text { December } \\
2000\end{array}$ & Environmental watershed & $\begin{array}{c}\text { But he's suspicious of technology that offers all the answers when the public is still } \\
\text { coming to grips with the questions surrounding waste water. } \\
\text { Questions do exist over the safety of recycled water, despite the } \\
\text { treatment processes. }\end{array}$ \\
\hline 13 March 2004 & Coast recycling order & $\begin{array}{l}\text { DEVELOPERS will be forced to install recycled water systems and rainwater tanks } \\
\text { in one of the Gold Coast's boom areas to help the region's water supply cope with } \\
\text { surging population growth. Gold Coast City Council yesterday approved the } \\
\text { Pimpama-Coomera Waterfuture, a plan designed to cut water consumption in the } \\
\text { Coast's fast-growing northern corridor by almost } 85 \text { percent. Rainwater tanks and } \\
\text { dual reticulation water systems will be mandatory in all new subdivisions. }\end{array}$ \\
\hline $\begin{array}{l}20 \text { February } \\
2005\end{array}$ & Wild about water party & $\begin{array}{l}\text { Water recycling and conservation projects nationwide have been mismanaged or } \\
\text { disappointing in the results they've achieved. }\end{array}$ \\
\hline 29 July 2005 & Sewage on tap & $\begin{array}{l}\text { IS RECYCLED sewage water likely to be your cup of tea-or, more exactly, would } \\
\text { you like it in your cup of tea? } \\
\text { As unpalatable as it may seem on the surface, it is something Australians may have } \\
\text { to come to terms with sooner rather than later as the demand for water outstrips } \\
\text { supply from dams, rivers and rainfall. }\end{array}$ \\
\hline $\begin{array}{l}13 \text { August } \\
2006\end{array}$ & $\begin{array}{l}\text { You might be drinking } \\
\text { it already }\end{array}$ & $\begin{array}{l}\text { PEOPLE in at least } 30 \text { Queensland towns are unwittingly drinking } \\
\text { recycled sewage. }\end{array}$ \\
\hline 8 May 2009 & $\begin{array}{l}\text { Goalposts moved on recycled } \\
\text { water guidelines }\end{array}$ & $\begin{array}{l}\text { The report, by the Queensland Water Commission's advisory board on recycled } \\
\text { water, said tests of samples produced out of the Western Corridor Recycled Water } \\
\text { project had detected bromodichloromethane, a byproduct of chlorination that is } \\
\text { known to cause liver cancer in animals. }\end{array}$ \\
\hline $\begin{array}{l}11 \text { November } \\
2009\end{array}$ & $\begin{array}{l}\text { Recycled water solution for } \\
\text { Anna Bligh }\end{array}$ & $\begin{array}{l}\text { Residents are already paying through the nose for this water. } \\
\text { The water in that pipe has passed stringent health standards and has been } \\
\text { produced by technology that is state-of-the-art. }\end{array}$ \\
\hline $\begin{array}{l}13 \text { December } \\
2010\end{array}$ & $\begin{array}{l}\text { Secret dossier exposes water } \\
\text { woes dogging Bligh } \\
\text { Government }\end{array}$ & $\begin{array}{l}\text { They include major blunders never publicly revealed until today, including the } \\
\$ 2.3 \text { million spent upgrading Queensland Water Commission's office, which is now } \\
\text { half-empty because of its reduced role, and concerns about "rogue" recycled water } \\
\text { test results. }\end{array}$ \\
\hline $\begin{array}{l}12 \text { August } \\
2013\end{array}$ & $\begin{array}{l}\text { EDITORIAL: Good sense ran } \\
\text { dry in costly water solutions }\end{array}$ & $\begin{array}{l}\text { Peter Beattie unveiled this radical scheme to turn sewage into drinking water in } \\
\text { 2007, at the height of southeast Queensland's worst drought in decades. } \\
\text { He planned three state-of-the-art treatment plants linked by a } 200 \mathrm{~km} \text { pipeline } \\
\text { from Luggage Point in the east to Wivenhoe Dam in the west. }\end{array}$ \\
\hline $\begin{array}{l}\text { 13 September } \\
2013\end{array}$ & $\begin{array}{l}\text { Billions down drain as plug } \\
\text { pulled on scheme }\end{array}$ & $\begin{array}{l}\text { A WATER recycling "white elephant" has cost Queensland taxpayers more than } \\
\$ 2.7 \text { billion and the bill keeps rising. The Beattie government's Western Corridor } \\
\text { Recycling Scheme was mothballed last month, and State Parliament has been told } \\
\text { it was "defunct", and shaping as a bigger fiscal folly than the Queensland Health } \\
\text { payroll debacle. }\end{array}$ \\
\hline $\begin{array}{l}23 \text { September } \\
2014\end{array}$ & Bill hike creates water torture & $\begin{array}{c}\text { The charge goes towards paying down debt for } \$ 7 \text { billion of water infrastructure } \\
\text { bought by the former Labor government during the drought, which includes some } \\
\text { white elephant projects such as the mothballed Tugun desalination plant and } \\
\text { retired Western Corridor Recycling Plant. }\end{array}$ \\
\hline
\end{tabular}


Table 4. Cont.

\begin{tabular}{ccc}
\hline Date & Title & Phrases \\
\hline $\begin{array}{c}31 \text { January } \\
2015\end{array}$ & LABOR RECYCLED & $\begin{array}{c}\text { The gang of five were members of governments which squandered billions of } \\
\text { taxpayer dollars on botched hospital projects, the payroll disaster, the flawed water } \\
\text { grid and the failed desalination plant. }\end{array}$ \\
\hline 27 July 2016 & 10 years ago & $\begin{array}{c}\text { TOILET-TO-TAP POLL: Queensland voters appear headed for an early election } \\
\text { with the main issue being the proposal to add recycled sewage to the southeast's } \\
\text { dwindling water supplies. Premier Peter Beattie yesterday said he might seek an } \\
\text { election mandate from voters to add recycled water into the region's major dams. } \\
\text { Mr. Beattie will use this weekend's referendum on recycled sewage in Toowoomba } \\
\text { as a touchstone towards community attitudes to the controversial water proposal. }\end{array}$ \\
\hline $\begin{array}{c}\text { 20 August } \\
\text { 2016 }\end{array}$ & BILLION DOLLAR BURDEN & $\begin{array}{c}\text { A State Government estimates hearing was told the unused \$2.7 billion Western } \\
\text { Corridor recycled water pipeline is costing \$10 million a year to maintain. }\end{array}$ \\
\hline $\begin{array}{c}\text { 18 February } \\
2017\end{array}$ & $\begin{array}{c}\text { Watching use now can save } \\
\text { pain later }\end{array}$ & $\begin{array}{c}\text { So it would be easy to forget the severity of those long dry years between 2001 and } \\
\text { 2009, the Millennium Drought, when southeast Queensland stared at the threat of } \\
\text { running out of water and Toowoomba had to vote on whether to drink } \\
\text { recycled sewage. }\end{array}$ \\
\hline 13 April 2018 & $\begin{array}{c}\text { Timers come back to haunt us } \\
\text { as water price hikes hit }\end{array}$ & $\begin{array}{c}\text { The multibillion-dollar spending spree on pipelines, desalination plants and } \\
\text { a recycled water scheme that followed is still hurting households. }\end{array}$ \\
\hline
\end{tabular}

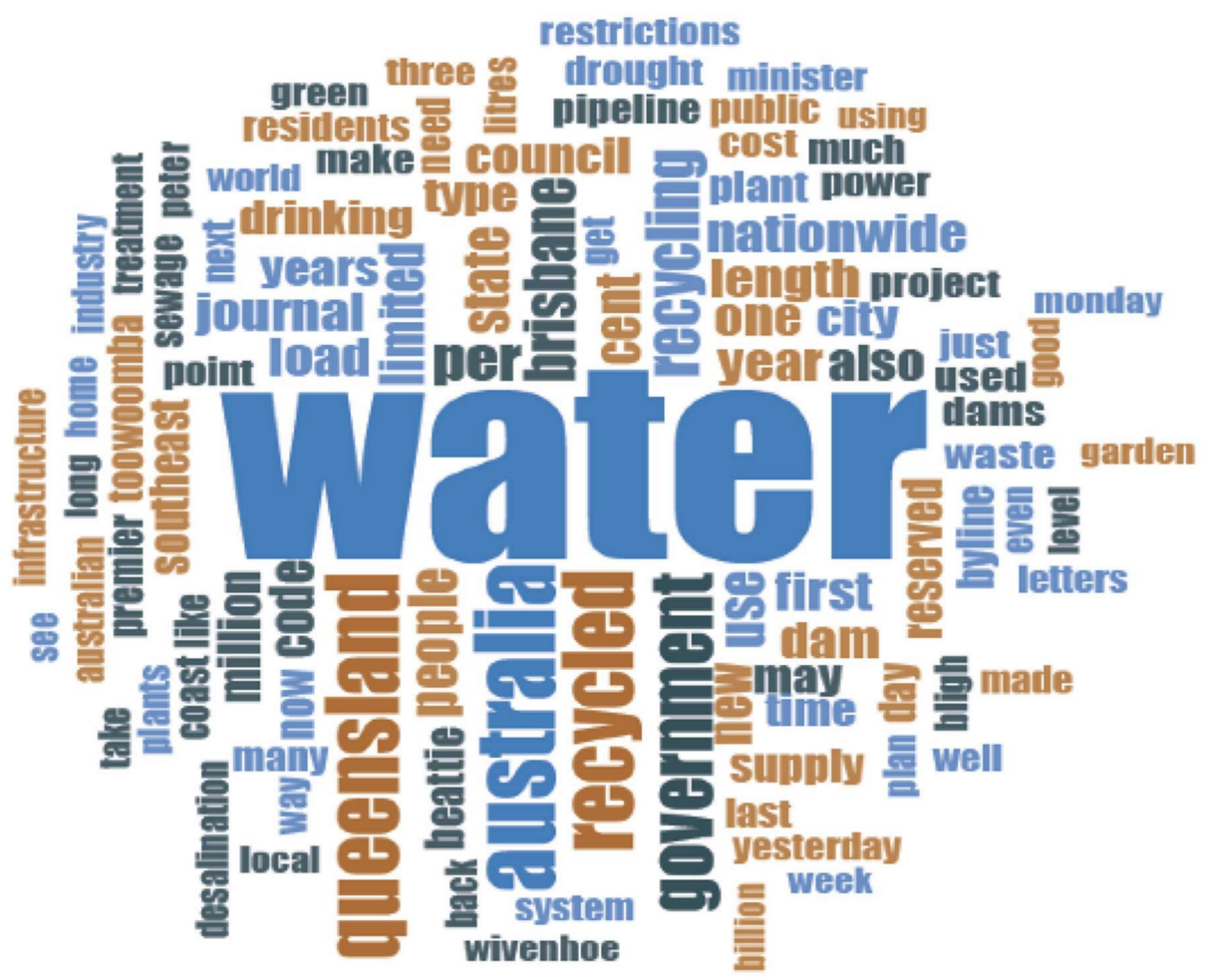

Figure 4. The Courier-Mail: terms associated with potable water reuse.

As with the other three newspapers, the most frequent word is 'water', followed by the location, in this case 'Queensland'. Articles also focused on 'sewage' and 'recycling' (although with a completely different connotation compared to the previous three newspapers), infrastructure such as 'pipelines' and, 'dams', 'desalination' and 'restrictions' and 'droughts'. Also mentioned is 'Toowoomba', which in the context of potable water reuse, is often linked to its rejection, Frequent use of words such as 'sewage' and 'waste' in The Courier-Mail's coverage may have created doubts about water recycling by emphasising an unpalatable frame.

Compared to the coverage in The Straits Times, few words focus on the technological process to recycle water. This could have increased public doubt about the thoroughness of the recycling process. Furthermore, the focus on words such as 'cost' may have created leeway for water recycling to be seen as financially unviable. Relative to the other word clouds, the word 'government' is used very often. This could have helped the issue of recycling be politicised, as it was. 


\section{Discussions and Conclusions}

The importance of the media and of communication regarding potable reused water has been discussed earlier, as well as the responses of populations to media messages [9-14,63,114-117], and societal views on alternative sources of water [12,117-121]. Here we discuss the views of the media, policymakers and water utility managers on the technology to produce potable reused water. We also discuss the role potable reused water plays in the three different locations and how it is perceived in each one of them.

Among the distinguishing factors in The Straits Times' coverage is the consistency of the message. In contrast to the Los Angeles Times and the Courier-Mail, the coverage of reused potable water in the Straits Times was more objective and significantly less emotive. The framing of technology by Singapore's policymakers and experts is also consistent, and are positive. Messages in the Straits Times focus on the end-product rather than the source water, as well as the thoroughness of the treatment, and how advanced the technology used is. Policymakers and experts unanimously express support for this technology because it is both cost-effective and cutting-edge.

The Los Angeles Times presents nuanced coverage on potable reused water. Messages focus on the cleanliness of the water but recognises that there has been aversion to it; emotional reactions are addressed. At the same time, policymakers and experts characterise the technology as cutting-edge and able to produce safe water. While the coverage remains objective, it is far less uniform than that of the Straits Times.

The Courier-Mail presents a mostly unfavourable view. Coverage of the technology, where present, has a more positive tone, but it is far outweighed by negative coverage. While a direct correlation cannot be drawn, it is likely that the newspaper coverage played a significant role in the relative unpopularity of the water source in Queensland.

In the Los Angeles Times and the Orange County Register, the technology is framed very positively. While the expression 'toilet-to-tap' is used, it is in the context of improved technology to produce clean water and meet water needs. In the Courier-Mail, the phrase has a more negative connotation, and used to describe a process that is very expensive and results in water that is not necessarily safe to drink.

In contrast with the framing of potable water reuse technology by Singapore's policymakers and experts, there is no unanimity in the messages from Queensland's politicians and experts as presented in the Courier-Mail. Some experts emphasise the cleanliness of the end product, mention the advanced level of technology, and pitch it as a significant investment. They also stress the importance of guidelines for water quality. However, others refer to the technology as being very expensive and with potential negative impacts on the economy. The Western corridor and related infrastructure are referred to as a water recycling "white elephant" that cost the taxpayer more than $\$ 2.7$ billion.

In the Courier-Mail, the focus is on the source water with its associated 'yuck factor', while in the other three newspapers it is merely a source of water, and the focus is on the final product, as part of an overall strategy of long-term water security. In the Courier-Mail, potable reused water is referred to as recycled sewage, and its safety is sometimes questioned. In Singapore and Orange Country, the polarity is reversed: the end product is highlighted, and it is referred to as ultrapure water.

In this framing, safety is not a concern, because protocols have been put in place and quality has been assured. In Queensland, experts acknowledge the value of potable reused water in augmenting water supply during periods of drought. However, in Singapore and in Orange County, potable reused water is portrayed as valuable not only during periods of drought but also because of the broader role it can play in security, resilience, and self-sufficiency in the long term.

In both Singapore and Orange County, there have been long-term public engagement efforts. In both contexts, these efforts have been so successful that potable reused water is widely accepted. As discussed by Ormerod and Silvia [117] in their analysis of the newspaper coverage of the Orange County Water District Groundwater Replenishment System between 2000 and 2016, coverage was either neutral or positive. They found no negative coverage. On the contrary, the authors 
mention that coverage could be portrayed as 'mundane'. Some of the positive comments framed the infrastructure and technology as means to develop sources of water while protecting human and environmental health.

In Singapore, NEWater is an essential element in present and future development, and it has been presented as such to the public. Most people are aware that the city-state is water-scarce because is too small to be able to store the high rainfall it receives (approximately $2500 \mathrm{~mm} /$ year). Thus, the public appreciate the importance of NEWater for water security and self-sufficiency.

In January-March 2014, a record dry spell (less than $1 \mathrm{~mm}$ of rainfall registered at a climatological station) affected Singapore, Malaysia and parts of Indonesia [122]. During this time, the National Environment Agency and PUB kept people informed of meteorological conditions and forecasts for Singapore. The media coverage was extensive in both Singapore and Malaysia. While there was rationing for domestic users in some cities in Malaysia, it was not necessary in Singapore, where life went on as normal, except for the PUB's constant reminders about water conservation. People were also reminded that this resilience was the result of the buffer provided by NEWater, with up to 30 MGD pumped into the reservoirs in January [123]. The people of Singapore understand the advantages of NEWater within the overall framework of water security.

The understanding of water scarcity and 'near-unanimous' concern for future water supplies is not limited to Singapore. Ormerod and Scott [124] studied the support of the population for water reuse in Tucson, Arizona. While the population was supportive of non-potable purposes, they were hesitant about potable reuse. However, this may be about to change. In September 2016, a pilot project for potable reuse by Tucson Water received a prize for its leadership in resource recovery, watershed protection, culture change and community partnering - that is, for aspects much broader than just the production of potable reused water. It may be that the city is preparing to provide additional sources of safe water, should it be required in the future.

In terms of planning and implementation, technology does not seem to be the main barrier to expanding water reuse operations for potable purposes. As discussed by the Urban Land Institute [125], the barriers have to do with institutional arrangements and regulation (coordinating overlapping regulatory requirements is crucial to implement the projects), and with community engagement. It is thus important for governments and utilities to address knowledge gaps [6] and to pursue research that facilitates risk assessment and informs policies and regulations [126]. Water rights is also an important topic that needs to be addressed.

As we have discussed, advances in the science and technology of potable water reuse, as well as more effective public communication, have helped reduce concerns about public health risks. They have also increased confidence in and acceptance of the practice among water practitioners and the public. Ppublic has become more receptive to the use of alternative sources of water due to increasing demands and the impacts of severe droughts [5].

Communities do not need water at any cost. They need reliable sources of safe water within a framework of sustainability, where the needs of all sectors will be covered on the long-term. Within this background, all water supply alternatives should be considered, and potable reused water has a very important role to play.

\section{Lessons Learnt}

Some of the lessons learnt of this study are as follows:

Climate change, droughts and water scarcity have become important factors in changing perceptions and attitudes of policymakers and communities to be more willing to consider reused water for potable use. There is a general realisation that there are not enough alternative sources of water to provide $24 \times 7$ safe water supply. As population increases, and with urbanisation and industrialisation, water is becoming increasingly scarce, making potable reused water a more likely resource to augment drinking water supplies. 
Human health and environmental concerns represent valid concerns for policymakers, regulators, public and the media. Since these concerns have been addressed properly when producing potable reused water, this message has to be communicated clearly.

Public messages should not be limited to the potential of potable water reuse. They should also include information on institutional coordination, regulatory, management and technological advances, which can and will reduce the concentration of chemicals and microbial contaminants to levels that are similar or lower than those in many high-quality drinking water supplies.

Public communications through the media play a central role in the development of public policies and their acceptance by the population. Water utilities timely information on potable reused water to the media and the population are likely to improve communication and understanding of the messages provided. Information and discussions on broader topics that affect reliable water supply would be useful for the communities to understand the potential of reused water to increase the quantity of safe water available for the domestic, industrial and agricultural sectors.

Media has the potential to influence public opinion on the provision of clean water through potable water reuse. This has been the case in Singapore, Orange County, and an increasing number of cities.

Regular contact between water utilities and media would be useful for the media to understand the relevance of efficient water management, especially during drought years, and the role reused water can play to ensure reliable supply of safe water. Media is essential to transmit this message to the general public.

With climate change and increasing intensities and magnitudes of droughts in coming decades, potable reused water is likely to become prevalent in cities in the United States and Europe. In addition, there are cities, such as Cape Town, where severe water scarcity resulting from extended droughts have made them consider production of reused water for potable purposes.

Cities where systems are well established as in Windhoek, Singapore and Orange County have become role models to study.

Author Contributions: C.T. conceived the idea. The draft was written, reviewed and edited in equal parts by both authors.

Funding: This research was funded by the Institute of Water Policy, Lee Kuan Yew School of Public Policy, National University of Singapore, grant number R-603-000-284-432. The APC was funded by the same institution.

Conflicts of Interest: The authors declare no conflict of interest.

\section{References}

1. Rice, J.; Wutich, A.; Westerhoff, P. Assessment of De Facto Wastewater Reuse across the U.S.: Trends between 1980 and 2008. Environ. Sci. Technol. 2013, 47, 11099-11105. [CrossRef] [PubMed]

2. U.S. Environmental Protection Agency (EPA). 2012 Guidelines for Water Reuse; EPA: Washington, DC, USA, 2012.

3. Australian Academy of Technological Sciences and Engineering (ATSE). Drinking Water through Recycling: The Benefits and Costs of Supplying Direct to the Distribution System; ATSE: Melbourne, Australia, 2013.

4. Foundation for Water Research. A Review of Current Knowledge: Water Reuse; FWR: Buckinghamshire, UK, 2016. Available online: http:/ / www.fwr.org/waterre/frr0024.pdf (accessed on 5 September 2018).

5. EPA-ReNUWIt-The Johnson Foundation. Mainstreaming Potable Water Reuse in the United States: Strategies for Leveling the Playing Field; EPA: Washington, DC, USA, 2018. Available online: https:/ / www.epa.gov/sites/production/files/2018-04/documents/mainstreaming_potable_water_ reuse_april_2018_final_for_web.pdf (accessed on 5 September 2018).

6. National Research Council. Water Reuse. Potential for Expanding the Nation's Water Supply through Reuse of Municipal Wastewater; The National Academies Press: Washington, DC, USA, 2012.

7. U.S. Environmental Protection Agency (EPA). 2017 Potable Reuse Compendium; EPA: Washington, DC, USA, 2017.

8. U.S. Environmental Protection Agency (EPA). Guidelines for Water Reuse; EPA: Washington, DC, USA, 2004. 
9. Po, M.; Kaercher, J.D.; Nancarrow, B.E. Literature Review of Factors Influencing Public Perceptions of Water Use; (Technical Report 54/03); CSIRO: Canberra, Australia, 2003. Available online: https:/ / www.clearwater.asn.au/user-data/research-projects / swf-files / 16-laying-the-foundationfor-confident-barrier-free-water-conservation-and-reuse-literature-review.pdf (accessed on 5 September 2018).

10. Harris-Lovett, S.; Sedlak, D. The History of Water Reuse in California. In Sustainable Water. Challenges and Solutions from California; Lassiter, A., Ed.; University of California Press: Berkeley, CA, USA, 2015; pp. 120-243.

11. City of San Diego Water Department. City of San Diego Water Reuse Study 2005: Water Reuse Goals, Opportunities \& Values. In Proceedings of the American Assembly Workshop I; San Diego, CA, USA, 6-7 October 2004. Available online: https://www.sandiego.gov/sites/default/files/legacy/water/pdf/purewater/ aa1wp.pdf (accessed on 5 September 2018).

12. Hurlimann, A.; Dolnicar, S. When Public Opposition Defeats Alternative Water Projects-The Case of Toowoomba Australia. Water Res. 2010, 44, 287-297. [CrossRef]

13. Leong, C. Eliminating "Yuck": A simple Exposition of Media and Social Change in Water Reuse Policies. Int. J. Water Resour. Dev. 2010, 26, 111-124.

14. Fielding, K.S.; Dolnicar, S.; Schultz, T. Public Acceptance of Recycled Water. Int. J. Water Resour. Dev. 2018. [CrossRef]

15. World Health Organization (WHO). Potable Reuse: Guidance for Producing Safe Drinking-Water; WHO: Geneva, Switzerland, 2017; Available online: http:/ /apps.who.int/iris/bitstream/handle/10665/258715/ 9789241512770-eng.pdf;jsessionid=8E2B6A894B4528F88C7E79BF0D453116? sequence=1 (accessed on 5 September 2018).

16. Macpherson, L.; Snyder, S. Downstream-Context, Understanding, Acceptance: Effect of Prior Knowledge of Unplanned Potable Reuse on the Acceptance of Planned Potable Reuse; Water Reuse Research Foundation: Alexandria, VA, USA, 2013.

17. Kemp, B.; Randle, M.; Hurlimann, A.; Dolnicar, S. Community Acceptance of Recycled Water: Can We Inoculate the Public Against Scare Campaigns? J. Public Aff. 2012, 12, 337-346. [CrossRef]

18. Singapore Government. Population Trends 2017; Singapore Department of Statistics: Singapore, 2017. Available online: https:/ / www.singstat.gov.sg/- / media/files/publications / population/population2017. pdf (accessed on 5 September 2018).

19. Singapore Government. Singapore in Figures 2017; Singapore Department of Statistics: Singapore, 2017. Available online: https://www.singstat.gov.sg/-/media/files/publications/reference/sif2017.pdf (accessed on 5 September 2018).

20. Central Intelligence Agency. The World Factbook. Available online: https://www.cia.gov/library/ publications/the-world-factbook/rankorder/2004rank.html (accessed on 10 September 2018).

21. Tortajada, C. Water Management in Singapore. Int. J. Water Resour. Dev. 2006, 22, 227-240. [CrossRef]

22. Public Utilities Board (PUB). Our Water, Our Future, Revised Edition; PUB: Singapore, 2018. Available online: https:/ / www.pub.gov.sg/Documents/PUBOurWaterOurFuture.pdf (accessed on 10 September 2018).

23. Lee, L.Y.; Ong, C.N. Frontier Research in Environment and Water: Integrated Research Approach for Sustainable Solutions. In 50 Years of Environment. Singapore Journey towards Environmental Sustainability; Tan, Y.S., Ed.; World Scientific: Singapore, 2016; pp. 85-125.

24. Public Utilities Board (PUB). NEWater; PUB: Singapore, 2018. Available online: https://www.pub.gov.sg/ watersupply/fournationaltaps / newater (accessed on 10 September 2018).

25. Lee, E.T. The Search for NEWater: The Singapore Water Story. In 50 Years of Environment. Singapore Journey towards Environmental Sustainability; Tan, Y.S., Ed.; World Scientific: Singapore, 2016; pp. 63-72.

26. Tortajada, C.; Joshi, Y.; Biswas, A.K. The Singapore Water Story. Sustainable Development in an Urban City-State; Routledge: London, UK, 2013.

27. Timm, S.; Deal, B. Understanding the Behavioral Influences behind Singapore's Water Management Strategies. J. Environ. Plan. Manag. 2017, 61, 1654-1673. [CrossRef]

28. United States Census Bureau. Quick Facts: California; U.S. Department of Commerce: Washington, DC, USA. Available online: https:/ / www.census.gov / quickfacts/CA (accessed on 10 September 2018). 
29. Holodny, E. California is Officially Bigger Than France. Business Insider, 15 June 2016. Available online: http:/ / www.businessinsider.sg/california-gdp-crushes-everyone-2016-6/?r=US\&IR=T (accessed on 10 September 2018).

30. Respaut, R. California Passes France as World's 6th-Largest Economy. Reuters, 2016. Available online: https:/ / www.reuters.com/article/us-california-economy-idUSKCN0Z32K2 (accessed on 10 September 2018).

31. U.S. News \& World Report. California. Available online: https://www.usnews.com/news/best-states/ california (accessed on 10 September 2018).

32. Crook, J. Regulatory Aspects of Direct Potable Reuse in California; National Water Research Institute: Fountain Valley, CA, USA, 2010.

33. Olivieri, A.; Crook, J.; Anderson, M.; Bull, R.; Drewes, J.; Haas, C. Evaluation of the Feasibility of Developing Uniform Water Recycling Criteria for Direct Potable Reuse; Expert Panel Final Report; California State Water Resources Control Board: Sacramento, CA, USA, 2016. Available online: https://www.waterboards.ca. gov/drinking_water/certlic/drinkingwater/documents/rw_dpr_criteria/app_a_ep_rpt.pdf (accessed on 10 September 2018).

34. California Department of Water Resources. Recycled Water Use in the Landscape. Sacramento, CA, USA. Available online: http:/ / www.water.ca.gov/pubs/conservation/recycled_water_use_in_the_landscape/ recylandscape.pdf (accessed on 10 September 2018).

35. Orange County Water District. President's Message; OCWD: Fountain Valley, CA, USA, 2016; Available online: https:/ /www.ocwd.com/news-events/newsletter/2016/september-2016/presidents-message/ (accessed on 15 July 2018).

36. Lohan, T. California Eyes Recycling Wastewater for Drinking. News Deeply, 2016. Available online: https:/ / www.newsdeeply.com/water/community/2016/07/15/california-eyes-recycling-wastewaterfor-drinking (accessed on 10 October 2018).

37. California Environmental Protection Agency. California Water Action Plan 2016 Update; CalEPA: Sacramento, CA, USA, 2016. Available online: http://resources.ca.gov/docs/california_water_action_plan/Final_ California_Water_Action_Plan.pdf (accessed on 15 October 2018).

38. California Government. Division of Drinking Water's Recycled Water Information (Announcements); California Water Boards: Sacramento, CA, USA, 2018. Available online: https:/ /www.waterboards.ca.gov/drinking water/certlic/drinkingwater/RecycledWater.html (accessed on 5 September 2018).

39. California Legislative Information. AB-574 Potable Reuse; Assembly Bill No. 574; Legislative Counsel State of California: Sacramento, CA, USA, 2017; Chapter 528. Available online: http:/ /leginfo.legislature.ca.gov/ faces/billNavClient.xhtml?bill_id=201720180AB574 (accessed on 7 October 2018).

40. State Water Resources Control Board (SWRCB). A Proposed Framework for Regulating Direct Potable Reuse in California; California Water Boards: Sacramento, CA, USA, 2018. Available online: https://www.waterboards.ca.gov/drinking_water/certlic/drinkingwater/documents/direct_ potable_reuse/dprframewk.pdf (accessed on 9 September 2018).

41. California Government. Water Recycling Funding Program; California Water Boards: Sacramento, CA, USA, 2018. Available online: https://www.waterboards.ca.gov/water_issues/programs/grants_loans/water_ recycling/water_recycling_funding_program.html (accessed on 10 October 2018).

42. House of Representatives. America's Water Infrastructure Act of 2018; Transportation and Infrastructure Committee: Minneapolis, MN, USA, 2018. Available online: https://transportation.house.gov/ uploadedfiles/s_3021_americas_water_infrastructure_act_of_2018.pdf (accessed on 5 September 2018).

43. Law, I. An Australian Perspective on DPR: Technologies, Sustainability and Community Acceptance. J. Water Reuse Desalin. 2016, 6, 355-361. [CrossRef]

44. Queensland Government Data. Registered Recycled Water Schemes; Queensland Government: Brisbane, Australia, 2018. Available online: https://data.qld.gov.au/dataset/registered-recycled-water-scheme/ resource/3d718d43-73f1-4c8e-b408-05f6c5429694 (accessed on 1 August 2018).

45. Verdict Media Limited. Western Corridor Recycled Water Project-Australia. Available online: http: / / www.water-technology.net/projects/western-corridor/ (accessed on 10 August 2018).

46. Seqwater. The Western Corridor Recycled Water Scheme is a Climate-Resilient Source of Water That Will Help Provide Water Security in Times of Need. Available online: http:/ / www.seqwater.com.au/watersupply / water-treatment/purified-recycled-water (accessed on 1 June 2018). 
47. Van Vuuren, K. Press Bias and Local Power in the Toowoomba Water Referendum. Commun. Polit. Cult. 2009, 42, 55-74.

48. Qld Govt Expects Recycled Water by 2008. The Sydney Morning Herald, 2007. Available online: http:/ / www.smh.com.au/news/National/Qld-govt-expects-recycledwater-by-2008/2007/01/28/ 1169919196919.html (accessed on 15 October 2018).

49. Drechsel, P.; Qadir, M.; Wichelns, D. (Eds.) Wastewater: Economic Asset in an Urbanizing World; Springer: Dordrecht, The Netherlands, 2015.

50. Lee, M.K. Digital News Consumption in Singapore on the Rise. The Straits Times Remains Most-read English Paper: Nielsen Survey. The Straits Times. 2017. Available online: https:/ /www.straitstimes.com/singapore/ digital-news-consumption-in-singapore-on-the-rise-the-straits-times-remains-most-read (accessed on 15 October 2018).

51. The Straits Times Remains the Most-read English Paper in Singapore: Nielsen Survey. The Straits Times. 2016. Available online: http:/ / www.straitstimes.com/singapore/the-straits-times-remains-the-most-readenglish-paper-in-singapore-nielsen-survey (accessed on 15 September 2018).

52. Cision. Top 10 Daily California Newspapers. Available online: http://www.cision.com/us/2010/03/top10-daily-california-newspapers / (accessed on 20 October 2018).

53. Pulitzer Prizes for the Los Angeles Times. Los Angeles Times. 2016. Available online: http:/ /www.latimes. com/about/la-times-pulitzer-prizes-htmlstory.html (accessed on 22 October 2018).

54. Nielsen: Courier-Mail Grows Online Readership with Mobile, Tablet Audience. The Courier-Mail. 2017. Available online: https:/ / www.couriermail.com.au/business/nielsen-couriermail-grows-online-readershipwith-mobile-tablet-audience/news-story/3cb9c9923cf86061802c340e0df23c7d (accessed on 16 October 2018).

55. Ng, J.H. How Singapore Will Never Go Thirsty. The Straits Times. 2016. Available online: http://www. straitstimes.com/opinion/how-singapore-will-never-go-thirsty (accessed on 15 October 2018).

56. Kwang, H.F. What's Next After Newater. The Straits Times. 2016. Available online: https://www.straitstimes. com/singapore/environment/whats-next-after-newater (accessed on 15 October 2018).

57. Biswas, A.K.; Tortajada, C. Drastic Action Needed to Cut Water Use Here. The Straits Times. 2017. Available online: http:/ / www.straitstimes.com/opinion/drastic-action-needed-to-cut-water-use-here-world-waterday (accessed on 16 October 2018).

58. Jarvis, D.S.L.; Ching, L.; Howlett, M.P.; Fraser, S.; Migone, A. Beyond the Individual in Controversial Science-Based Technology Attitude Formation and Regulation: The State Construction of Policy Alternatives in Asia. Lee Kuan Yew School of Public Policy Research Paper No. LKYSPP10-10. 27 November 2010. Available online: https: / / papers.ssrn.com/sol3/papers.cfm?abstract_id=1717515 (accessed on 22 October 2018).

59. Lim, Y.L. Bottled Wonder. The Straits Times. 2015. Available online: http://www.straitstimes.com/singapore/ bottled-wonder (accessed on 20 October 2018).

60. Lin, Y. Keeping Singapore's Taps Flowing in the Quest for a Robust Water Supply. The Straits Times. 2017. Available online: http:/ / www.straitstimes.com/singapore/keeping-the-nations-taps-flowing (accessed on 15 October 2018).

61. Lin, Y. Desalination Underground, Recreation Above. The Straits Times. 2017. Available online: http: / / www.straitstimes.com/singapore/environment/desalination-underground-recreation-above (accessed on 19 October 2018).

62. Lim, J. Water World: A Look at 5 Reservoirs in Singapore. The Straits Times. 2016. Available online: http:// www.straitstimes.com/singapore/environment/water-world-a-look-at-5-reservoirs-in-singapore (accessed on 10 October 2018).

63. Dolnicar, S.; Hurlimann, A.; Nghiem, L.D. The Effect of Information on Public Acceptance-The Case of Water from Alternative Sources. J. Environ. Manag. 2010, 91, 1288-1293. [CrossRef] [PubMed]

64. PUB Calls Tender for Expansion of Changi Water Reclamation Plant. The Straits Times. 2016. Available online: http:/ / www.straitstimes.com/singapore/environment/pub-calls-tender-for-expansion-of-changiwater-reclamation-plant (accessed on 11 October 2018).

65. Khew, C. Singapore's Water Success Has H2O Expert Worried. The Straits Times. 2016. Available online: http:/ / www.straitstimes.com/singapore/environment/singapores-water-success-has-h2o-expertworried (accessed on 15 October 2018). 
66. National Archives of Singapore. Speech by Prime Minister Goh Chok Tong at the Official Launch of Newater; Singapore Government Press Release: Singapore, 2003. Available online: http://www.nas.gov.sg/ archivesonline/speeches / view-html?filename=2003022102.htm (accessed on 21 October 2018).

67. National Archives of Singapore. Speech by Mr Lee Hsien Loong, Prime Minister at the Official Opening of Keppel Seghers Ulu Pandan NEWater Plant; Singapore Government Media Release: Singapore, 2007. Available online: http:/ / www.nas.gov.sg / archivesonline/ speeches / view-html?filename=20070315978.htm (accessed on 21 October 2018).

68. National Archives of Singapore. Speech by Mr Raymond Lim, Minister for Prime Minister's Office, 2nd Minister for Finance and Foreign Affairs, at the Ulu Pandan Newater Factory Foundation Laying Ceremony; Singapore Government Media Release: Singapore, 2005. Available online: http:/ /www.nas.gov.sg/archivesonline/ speeches $/$ view-html?filename=20050712996.htm (accessed on 21 October 2018).

69. Singapore Government. DPM Teo Chee Hean at the World Water Day Celebrations 2017; Prime Minister's Office: Singapore, 2017. Available online: http:/ / www.pmo.gov.sg/newsroom/dpm-teo-chee-hean-world-waterday-celebrations-2017 (accessed on 17 October 2018).

70. National Archives of Singapore. Statement by Mr Desmond Lee Special Envoy of the Prime Minister to the Third United Nations Conference on Housing and Sustainable Urban Development (Habitat III) and Senior Minister of State for Home Affairs and National Development; Singapore Government Media Release: Singapore, 2016.

71. National Archives of Singapore. Speech by Mr Goh Chok Tong, Senior Minister, at the Official Opening of Sembcorp's Newater Plant; Singapore Government Media Release: Singapore, 2010. Available online: http:// www.nas.gov.sg/archivesonline/speeches /view-html?filename=20100510001.htm (accessed on 17 October 2018).

72. Parliament of Singapore. Debate on Annual Budget; Parliament No. 13, Session No: 1, Volume No: 94, Sitting No: 37, Sitting Date: 02-03-2017, Section Name: Budget; 2017. Available online: http:/ /sprs.parl.gov.sg/ search / topichtmlfilename=008_20170302_S0004_T0001 (accessed on 12 October 2018).

73. Singapore Government. Speech by President Tony Tan Keng Yam at the Opening Ceremony and Welcome Reception of the World Cities Summit, Singapore International Water Week and Cleanenviro Summit; Ministry of Communications and Information: Singapore, 2016. Available online: https: / /www.gov.sg/ \{\}/sgpcmedia/media_releases/istana/speech/S-20160710-1/attachment/ President $\% 20$ Tony\%20Tan\%27s\%20speech\%20at\%20World\%20Cities\%20Summit.pdf (accessed on 20 October 2018).

74. Stevens, M. California Seeks to Build One of World's Largest Recycled Water Programs. Los Angeles Times. 2015. Available online: http:/ / www.latimes.com/local/lanow/la-me-ln-mwd-recycled-water-20150922story.html (accessed on 16 October 2018).

75. Morin, M. Purified Wastewater Triggers Release of Arsenic within Aquifer, Study Finds. Los Angeles Times. 2015. Available online: http:/ / www.latimes.com/science/sciencenow/la-sci-sn-arsenic-water-20150904story.html (accessed on 15 December 2018).

76. Sims, J.H.; Baumann, D.D. Renovated Waste Water: The Question of Public Acceptance. Water Resour. Res. 1974, 10, 659-665. [CrossRef]

77. Haefele, M.B.; Sklar, A. Revisiting 'Toilet to Tap'. Los Angeles Times. 2007. Available online: http:/ /www. latimes.com/opinion/la-op-haefele26aug26-story.html (accessed on 9 October 2018).

78. Boxall, B. Severe Drought? California Has Been Here Before. Los Angeles Times. 2014. Available online: http: / / articles.latimes.com/2014/feb/23/local/la-me-drought-weakness-20140223/2 (accessed on 9 October 2018).

79. MWD's Water Recycling Plan is a Good One, but Don't Call it 'Toilet to Tap'. Los Angeles Times. 2015. Available online: http:/ /www.latimes.com/opinion/editorials/la-ed-0924-mwd-20150924-story.html (accessed on 9 October 2018).

80. Hiltzik, M. As Political Pressure for Approval Intensifies, the Case for a Big Desalination Plant Remains Cloudy. Los Angeles Times. 2017. Available online: http:/ / www.latimes.com/business/hiltzik/la-fi-hiltzikdesalination-20170521-story.html (accessed on 9 October 2018).

81. McIntyre, M. All that Water, Every Drop to Drink. Los Angeles Times. 2008. Available online: http:// www. latimes.com/opinion/la-op-snow-mcintyre10apr10-story.html (accessed on 9 October 2018). 
82. Masunaga, S. Rosemead Cemetery Aims to be a Model of Drought-tolerant Landscaping. Los Angeles Times. 2014. Available online: http:/ / www.latimes.com/local/california/la-me-rosemead-cemetery-20141214story.html (accessed on 9 October 2018).

83. Fleischer, M. Don't Gag: It's Time for L.A. to Embrace 'Toilet to Tap' Water. Los Angeles Times. 2014. Available online: http:/ / articles.latimes.com/2014/feb/04/news/la-ol-drought-toilet-to-tap-water20140204 (accessed on 9 October 2018).

84. Morin, M. Turning Sewage into Drinking Water Gains Appeal as Drought Lingers. Los Angeles Times. 2015. Available online: http:/ / www.latimes.com/local/california/la-me-toilet-to-tap-20150525-story.html (accessed on 9 October 2018).

85. Recycled Wastewater: Get Over the 'Yuck Factor'. Los Angeles Times. 2015. Available online: http: / / www. latimes.com/opinion/readersreact/la-le-0529-friday-water-sewage-20150529-story.html (accessed on 9 October 2018).

86. U.S. Government Publishing Office. H.R.1869, Environmental Compliance Cost Transparency Act of 2015; H.R. 2993, Water Recycling Acceleration Act of 2015; and H.R. 4582, Save Our Salmon (SOS) ACT (Legislative Hearing); U.S. Government Publishing Office: Washington, DC, USA, 2016. Available online: https:/ /www.gpo.gov/ fdsys/pkg/CHRG-114hhrg99892/html/CHRG-114hhrg99892.htm (accessed on 10 October 2018).

87. Congress.Gov. H.R.2993, Water Recycling Acceleration Act of 2015; Library of Congress: Washington, DC, USA, 2015. Available online: https:/ / www.congress.gov/bill/114th-congress/house-bill/2993 (accessed on 10 October 2018).

88. Water Recycling Efforts Spark Policy Debate in California. PBS News Hour. 2008. Available online: https: / / www.pbs.org/newshour/show/water-recycling-efforts-spark-policy-debate-in-california (accessed on 10 October 2018).

89. Madigan, M. Campbell Newman Struggles to Meet Water Price Pledge as Queenslanders Save Every Drop. The Courier-Mail. 2012. Available online: http://www.couriermail.com.au/news/ queensland/revenue-dries-up-in-water-torture/news-story /308c5cd842465f3bdfe04237fddc69b2?sv= acba1aff86c577500067c1076cb1e119 (accessed on 10 October 2018).

90. Wardill, S.; Johnstone, C. Anna Bligh Defends \$2b Recycled Water Pipeline. The Courier-Mail. 2009. Available online: http:/ / www.couriermail.com.au/news / queensland/bligh-defends-recycled-pipeline/news-story/ aa5f80507d5c1894df937db844e7986a?sv=6c2c10a5e5d48cb332f9c73b19a55f09 (accessed on 10 October 2018).

91. Johnstone, C. Recycled Water Solution for Anna Bligh. The Courier-Mail. 2009. Available online: http:/ / www.couriermail.com.au/news/queensland/recycled-water-solution-for-anna-bligh/newsstory /28679201dca68d06251cecf4189a3c1c?sv=a1609cd9f659afc82bda1ca5b859d8aa (accessed on 10 October 2018).

92. Wardill, S. Secret Dossier Exposes Water Woes Dogging Bligh Government. The Courier-Mail. 2010. Available online: http://www.couriermail.com.au/news/queensland/secret-dossierexposes-water-woes-dogging-bligh-government/news-story /e1d5ff231e4655f40889f08d799f31ac? $\mathrm{sv}=867 \mathrm{e}$ bafe4ab7e18f15e417a225ce2f0 (accessed on 10 October 2018).

93. Johnstone, C. Goalposts Moved on Recycled Water Guidelines. The Courier-Mail. 2009. Available online: https: / www.couriermail.com.au/news/queensland/recycled-water-standards-slip/news-story/ 5c885fa048c6db0f1300002ba428281e?sv=fff7610ae54cc41201a2c9953a702897 (accessed on 10 October 2018).

94. Editorial: Good Sense Ran Dry in Costly Water Solutions. The Courier-Mail. 2013. Available online: http:/ / www.couriermail.com.au/news/opinion/editorial-good-sense-ran-dry-in-costly-watersolutions / news-story/355c526b6f4b4fc01b61fb9c30765b07 (accessed on 10 October 2018).

95. You Might Be Drinking It Already. The Courier-Mail. 2016. Available online: http: / / www.couriermail.com.au/news/special-features/you-might-be-drinking-it-already/news-story / 13b4576cb55472f53e9ba64599ac93a6?sv=c9dcb53b264571ff5a953a06e52fe4b3 (accessed on 10 October 2018).

96. Dolnicar, S.; Hurlimann, A. Desalinated Versus Recycled Water-What Does the Public Think. In Sustainable Water for the Future: Water Recycling Versus Desalination; Escobar, I., Schafer, A., Eds.; Elsevier: Amsterdam, The Netherlands, 2010; pp. 375-388.

97. Queensland Parliament. Question on Notice No. 1092 Asked on 27 October 2015, Mr Hart Asked the Minister for Main Roads, Road Safety and Ports and Minister for Energy and Water Supply (Hon M Bailey); Government of Australia: Canberra, Australia, 2015. 
98. Queensland Parliament. Question on Notice No. 513 Asked on 7 August 2013, Mr Grant Asked the Minister for Energy and Water Supply (Mr MCardle); Government of Australia: Canberra, Australia, 2013.

99. Queensland Parliament. Water Legislation (Dam Safety and Water Supply Enhancement) and Other Legislation Amendment Bill 2012; Government of Australia: Canberra, Australia, 2012.

100. Queensland Parliament. Question on Notice No. 1103 Asked on 9 August 2007, Ms Palaszczuk asked the Minister for Natural Resources and Water and Minister Assisting the Premier in North Queensland (Mr Wallace); Government of Australia: Canberra, Australia, 2007.

101. Queensland Parliament. Question on Notice No. 832 Asked on 25 May 2011, Mr Rickuss asked the Minister for Energy and Water Utilities (Mr Robertson); Government of Australia: Canberra, Australia, 2011.

102. Queensland Audit Office. Maintenance of Water Infrastructure Assets. Report to Parliament 14: 2012-13; QAO: Brisbane, Australia, 2013.

103. Queensland Parliament. Question on Notice No. 187 Asked on 1 March 2006, Mr Choi asked the Minister for Natural Resources, Mines and Water (Mr Palaszczuk); Government of Australia: Canberra, Australia, 2006.

104. Queensland Parliament. Question on Notice No. 791 Asked on 21 June 2002, Mr Flynn asked the Premier and Minister for Trade (MR BEATTIE); Government of Australia: Canberra, Australia, 2002.

105. Queensland Parliament. Question on Notice No. 1633 Asked on 30 October 2008, Mr Moorhead asked the Deputy Premier and Minister for Infrastructure and Planning (Mr Lucas); Government of Australia: Canberra, Australia, 2008.

106. Queensland Parliament. Question on Notice No. 122 Asked on 8 February 2007, Mr Gibson asked the Deputy Premier, Treasurer and Minister for Infrastructure (Ms Bligh); Government of Australia: Canberra, Australia, 2007.

107. Queensland Parliament. Question on Notice No. 583 Asked on 17 April 2008, Mrs Attwood asked the Deputy Premier and Minister for Infrastructure and Planning (Mr Lucas); Government of Australia: Canberra, Australia, 2008.

108. Queensland Parliament. Question on Notice No. 1217 Asked on 23 August 2005, Mr Livingstone asked the Premier and Treasurer (Mr Beattie); Government of Australia: Canberra, Australia, 2005.

109. Queensland Parliament. Question on Notice No. 1920 Asked on 23 November 2005, Mr Messenger asked the Minister for Environment, Local Government, Planning and Women (Ms Boyle); Government of Australia: Canberra, Australia, 2005.

110. Letter from Prime Minister John Howard to Premier of Queensland, Canberra; Government of Australia: Canberra, Australia, 2002.

111. Letter from Dan Galligan, Chief Executive Officer of the Queensland Farmers Federation to The Research Director, State Development, Infrastructure and Industry Committee, Parliament House, Queensland; Queensland Farmers' Federation: Brisbane, Australia, 2013.

112. Queensland Parliament. Public Inquiry_Inquiry into the Queensland Audit Office Report to Parliament No. 14 for 2012-13, Maintenance of Water Infrastructure Assets on 20 November 2013; State Development, Infrastructure and Industry Committee: Brisbane, Australia, 2013.

113. Queensland Parliament. Question on Notice No. 830 Asked on 14 May 2008, Miss Simpson Asked the Deputy Premier and Minister for Infrastructure and Planning (Mr Lucas); Government of Australia: Canberra, Australia, 2008.

114. Chen, Z.; Ngo, H.H.; Guo, W.; Wang, X.C.; Miechel, C.; Corby, N.; Listowski, A.; O’Halloran, K. Analysis of Social Attitude to the New End Use of Recycled Water for Household Laundry in Australia by the Regression Models. J. Environ. Manag. 2013, 126, 79-84. [CrossRef] [PubMed]

115. Goodwin, D.; Raffin, M.; Jeffrey, P.; Smith, H.M. Evaluating Media Framing and Public Reactions in the Context of a Water Reuse Proposal. Int. J. Water Resour. Dev. 2018, 34, 848-868. [CrossRef]

116. Leong, C. A Lived-experience Investigation of Narratives: Recycled Drinking Water. Int. J. Water Resour. Dev. 2016, 32, 637-649.

117. Ormerod, K.J.; Silvia, L. Newspaper Coverage of Potable Water Recycling at Orange County Water District's Groundwater Replenishment System, 2000-2016. Water 2017, 9, 984. [CrossRef]

118. Po, M.; Nancarrow, B.E.; Leviston, Z.; Porter, N.B.; Syme, G.J.; Kaercher, J.D. Predicting Community Behaviour in Relation to Wastewater Reuse: What Drives Decisions to Accept or Reject? CSIRO Land and Water: Acton, Australia, 2005. 
119. Garcia-Cuerva, L.; Berglund, E.Z.; Binder, A.R. Public Perceptions of Water Shortages, Conservation Behaviors, and Support for Water Reuse in the U.S. Resour. Conserv. Recycl. 2016, 113, 106-115. [CrossRef]

120. Dolnicar, S.; Hurlimann, A.; Grun, B. What Affects Public Acceptance of Recycled and Desalinated Water? Water Res. 2011, 45, 933-943. [CrossRef] [PubMed]

121. Wester, J.; Timpano, K.R.; Cek, D.; Braod, K. The Psychology of Recycled Water: Factors Predicting Disgust and Willingness to Use. Water Resour. Res. 2016, 52, 3212-3226. [CrossRef]

122. McBride, J.; Sahany, S.; Hassim, M.E.E.; Nguyen, C.M.; Lim, S.Y.; Rahmat, R.; Cheong, W.K. The 2014 Record Dry spell at Singapore: An Intertropical Convergence Zone (ITCZ) Drought. Bull. Am. Meteorol. Soc. 2015, 96, S126-S130. [CrossRef]

123. Dry Spell to Continue into Next Month. Today. 2018. Available online: https://www.todayonline.com/ singapore/dry-spell-continue-next-month (accessed on 15 October 2018).

124. Ormerod, K.J.; Scott, C.A. Drinking Wastewater: Public Trust in Potable Reuse. Sci. Technol. Hum. Values 2012, 38, 351-373. [CrossRef]

125. Urban Land Institute. Planning for Water Reuse. Shifting Policies toward Innovation in Southern California; Urban Land Institute: Irvine, CA, USA. Available online: https://orangecounty.uli.org/wp-content/uploads/ sites/41/2015/10/Planning-for-Water-Reuse-Spring-20151.pdf (accessed on 15 October 2018).

126. Rodriguez, C.; Van Buynder, P.; Lugg, R.; Blair, P.; Devine, B.; Cook, A.; Weinstein, P. Indirect Potable Reuse: A Sustainable Water Supply Alternative. Int. J. Int. Res. Public Health 2009, 6, 1174-1209. [CrossRef] [PubMed]

(C) 2019 by the authors. Licensee MDPI, Basel, Switzerland. This article is an open access article distributed under the terms and conditions of the Creative Commons Attribution (CC BY) license (http:/ / creativecommons.org/licenses/by/4.0/). 